PONTIFÍCIA UNIVERSIDADE CATÓLICA DO RIO DE JANEIRO

\title{
A Sustentabilidade e a Responsabilidade Socioambiental nas Instituições Financeiras: o exemplo do BNDES
}

Emilie Gurtin

Trabalho de Conclusão de Curso

Centro de CIÊnCIAS SOCIAIS - CCS

DEPARTAMENTO DE AdMINISTRAÇÃO

Graduação em Administração de Empresas 

หัฒ

Emilie Gurtin

A Sustentabilidade e a Responsabilidade Socioambiental nas Instituições Financeiras: o exemplo do BNDES

Trabalho de Conclusão de Curso

Trabalho de Conclusão de Curso, apresentado ao programa de graduação em Administração da PUC-Rio como requisito parcial para a obtenção do titulo de graduação em Administração.

Orientador: Ciro Valério Torres da Silva

Rio de Janeiro

junho de 2018. 


\section{Agradecimentos}

Agradeço primeiramente a Deus, por me dar forças e guiar o meu caminho, e a minha mãe, por todo amor, apoio e incentivo.

Agradeço também às minhas tias, por me apoiarem.

A todos os meus amigos e amigas da faculdade, sou grata pela motivação, momentos de alegria e conversas.

Ao meu orientador, minha gratidão, por ter me ajudado na elaboração deste trabalho. 


\section{Resumo}

Gurtin, Emilie. A Sustentabilidade e a Responsabilidade Socioambiental nas Instituições Financeiras: o exemplo do BNDES. Rio de Janeiro, 2018. 80 páginas. Trabalho de Conclusão de Curso - Departamento de Administração. Pontifícia Universidade Católica do Rio de Janeiro.

O objetivo deste trabalho foi mostrar a importância das Instituições Financeiras como instrumentos de propagação da responsabilidade socioambiental, através de sua influência sobre outras empresas, ao adotar e induzir práticas sustentáveis, através de suas políticas de financiamento e crédito. Para tal, foi feito um levantamento bibliográfico sobre o tema, com foco nos mecanismos de mercado e legislações vigentes relacionados à questão social e ambiental, tendo como principal exemplo o BNDES. O método de pesquisa utilizado foi do tipo qualitativo descritivo e foram utilizados dados secundários. Com os dados obtidos do BNDES foram feitos cruzamentos e observações das informações para destacar os mecanismos e políticas adotados pelo banco. Dessas observações, concluiu-se que o BNDES adota praticamente todos os mecanismos citados e está comprometido com a questão da sustentabilidade e responsabilidade socioambiental. Além disso, pode-se inferir também que se realmente as instituições financeiras adotarem os mecanismos e legislações existentes, elas podem influenciar e mesmo condicionar o mercado na direção de um desenvolvimento mais sustentável. Entretanto, essa atitude é só o primeiro passo e deve ser aperfeiçoada, com a participação de toda a sociedade.

Palavras- chave

Responsabilidade Socioambiental; Sustentabilidade; Instituições Financeiras; BNDES 


\section{Abstract}

Gurtin, Emilie. Sustainability and Social and Environmental Responsibility in Financial Institutions: the example of BNDES. Rio de Janeiro, 2018. 80 pages. Trabalho de Conclusão de Curso - Departamento de Administração. Pontifícia Universidade Católica do Rio de Janeiro.

The objective of this work was to show the importance of Financial Institutions as tools to spread social and environmental responsibility through their influence in the market, by adopting sustainable practices and thus conditioning the market by means of its financing and credit policies. For that purpose, a bibliographic research was made on the subject, on the market mechanisms, and on the current legislation related to social and environmental issues, having BNDES as the main example. The research method used was the qualitative descriptive type, and secondary data were used. With the information obtained at BNDES, cross-checkings and further observations were made in order to highlight the mechanisms and policies adopted by the bank. From such observations, we can conclude that BNDES adopts nearly all the mechanisms studied and is committed with sustainability and socio-environmental responsibility. In addition, we can also infer that, if financial institutions actually adopt existing mechanisms and legislation, they can influence and even condition the market towards a more sustainable development. However, this attitude is only the first step and must be perfected, with the participation of the whole society.

Key-words

Social and Environmental Responsibility; Sustainability; Financial Institution; BNDES 


\section{Sumário}

1. Introdução 10

$\begin{array}{ll}\text { 1.1. Objetivo } & 11\end{array}$

1.2. Relevância 11

1.3. Delimitação 12

2. Referencial Teórico 13

2.1. Sustentabilidade 13

$\begin{array}{ll}\text { 2.1.1. Tripé da Sustentabilidade } & 17\end{array}$

$\begin{array}{ll}\text { 2.2. Responsabilidade Socioambiental } & 18\end{array}$

2.2.1. Instituições financeiras 22

2.3. Mecanismos obrigatórios ou regulatórios 23

2.3.1. Resolução do Conselho Monetário Nacional n 4.327/2014 23

2.3.2. Normativo SARB da FEBRABAN n $14 / 2014$

2.3.3. Política Nacional do Meio Ambiente $n^{\circ}$ 6.938/81 24

2.3.3.1. Licenciamento Ambiental 25

2.3.4. Princípio Poluidor-Pagador (PPP) 25

2.3.5. Lei Anticorrupção $n^{\circ} 12.846 / 201326$

2.3.6. Lei dos Crimes contra o meio ambiente no 9.605/98 26

2.3.7. Política Nacional sobre Mudança do Clima n 12.187/2009 27

2.3.8. Criação do Fundo Nacional sobre Mudança do Clima Lei oㅡ $\begin{array}{ll}12.114 / 2009 & 27\end{array}$

2.3.9. Lei $n^{\circ}$ 12.305/2010: Política Nacional de Resíduos Sólidos 27

2.3.10. Código Florestal: Artigo78-A Lei no 12.651/2012 28

2.3.11. Decreto no 6.961/2009 28

2.3.12. Resoluções n $3.813 / 2009$ e n $3.814 / 2009$

2.3.13. Decreto ํㅜ 6.321/2017 29

2.3.14. Decreto no 6.514/2008 29

2.3.15. Resolução no 3.545/2008 29

2.3.16. Lei de Acesso à Informação № 12.527/2011 29

2.3.17. Lei $n^{0} 10.743 / 2003 \quad 30$ 
2.3.18. Lei de Responsabilidade das Estatais nำ 13.303/2016 30

2.3.19. Circular BACEN n ․678/2013 30

2.4. Mecanismos existentes no mercado 30

2.4.1. Pacto Global 30

2.4.1.1. Objetivos de Desenvolvimento Sustentável 31

2.4.2. Agenda $21 \quad 32$

2.4.3. Princípios do Equador 33

2.4.4. Protocolo Verde 35

2.4.5. GRI - Global Reporting Initiative 37

2.4.6. Indicadores Ethos de responsabilidade social 38

2.4.7. Fundos e títulos verdes de investimento 39

2.4.8. UNEP Finance Initiative (UNEP-FI) 40

2.4.9. Índice de Sustentabilidade Dow Jones (DJSI WORLD) 41

2.4.10. International Finance Corporation (IFC) 41

2.4.11. Índice de Sustentabilidade Empresarial da Bolsa de Valores de São Paulo (ISE-BOVESPA) 42

2.4.12. Gestão Ambiental 43

2.4.13. Normas ISO - International Standardization Organization 44

2.4.13.1. ISO $14000 \quad 44$

2.4.14. SA 8000 - Social Accountability 800045

2.4.15. ABNT NBR 16001:2004 - Responsabilidade Social - Sistema de $\begin{array}{ll}\text { gestão } & 46\end{array}$

2.4.16. ISO 26000 - Diretrizes em Responsabilidade Social 47

2.4.17. Carbon Disclosure Project (CDP) 48

3. Metodologia 49

3.1. Método de pesquisa utilizado 49

3.2. Procedimentos e instrumentos de coleta de dados utilizados no estudo 50

3.3. Análise dos dados coletados para o estudo 50

3.4. Limitações do Estudo 50

4. Apresentação e análise dos resultados 51

4.1. Banco Nacional de Desenvolvimento Econômico e Social 51 
4.2. Mecanismos Obrigatórios ou regulatórios

5. Conclusões

5.1. Sugestões de trabalhos futuros 68

Referências Bibliográficas 


\section{Lista de figuras}

Figura 1 Equilíbrio dinâmico da Sustentabilidade ............................................18

Figura 2 Os dez princípios do Pacto Global....................................................31

Figura 3: Objetivos de Desenvolvimento Sustentável ..........................................32

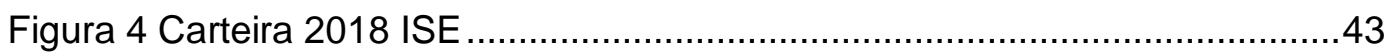

\section{Lista de tabela}

Tabela 1 Classificação do Risco Ambiental. 


\section{Introdução}

Nos dias atuais, cada vez mais o mundo vem sofrendo transformações que levam a todos, sociedade e empresas, a buscar soluções para enfrentar essas mudanças, visando um mundo mais sustentável. Com isso, a preocupação com o meio ambiente e o social está em alta. Essa preocupação só começou por volta dos anos 70 , quando o mundo começou a perceber que era necessário começar a se preocupar com o meio ambiente, pois entendeu que os recursos eram finitos e que era necessário conter esse crescimento desenfreado. Não havia preocupação com a utilização dos recursos naturais e com a humanidade. Foi assim que a ONU realizou em 1972 uma conferência em Estocolmo, para tratar desse tema. Nessa conferência foram estabelecidos os primeiros princípios visando minimizar os impactos no meio ambiente. No Brasil, a preocupação com o tema só começou por volta dos anos 80 , quando foi incluído um capitulo sobre o meio ambiente na Constituição de 1988. Não podemos nos esquecer também da conferência ECO 92, que aconteceu no Rio de Janeiro, em que foram apresentadas algumas ações visando o desenvolvimento sustentável dos países. Como desenvolvimento sustentável, entenda-se o crescimento e o desenvolvimento das nações, tendo em vista satisfazer as necessidades das atuais gerações sem comprometer as futuras (DIAS, 2007).

A participação da sociedade e das empresas na construção de um mundo mais sustentável é importante e necessário. Assim, as empresas possuem um papel relevante, de grande influência sobre toda a sociedade, como agentes de desenvolvimento, auxiliando na mudança social para a construção de um mundo mais sustentável e melhor (SIMÕES et al., 2008).

As empresas, como agentes de desenvolvimento, não devem ter sua estratégia baseada somente na dimensão econômica, mas também no social e no ambiental, ou seja, devem ter uma estratégia baseada no tripé da sustentabilidade, buscando uma atuação mais de longo prazo, considerando impactos não mercadológicos das decisões tomadas e procurando melhorar a sociedade com responsabilidade e sustentabilidade (INSTITUTO ETHOS, 2017).

No caso das instituições financeiras, elas possuem um papel importante, mesmo não exercendo uma atividade diretamente poluidora. Sendo assim, 
através de suas políticas de financiamento e crédito, podem impactar o mercado, tendo em vista o desenvolvimento sustentável, e diminuir os impactos derivados dessas operações. Elas devem incluir em suas políticas, critérios sociais e ambientais, além do econômico-financeiro (CEBDS, 2005). Ao aderir aos princípios do Equador, ao Pacto Global da ONU, à Agenda 21, ao Protocolo Verde, e ao respeitar as regras estabelecidas pelo Banco Central, incentivando os Fundos e Títulos Verdes de investimento, entre outras práticas e ferramentas que auxiliam nas finanças sustentáveis, as instituições financeiras podem ajudar em um desenvolvimento mais humano.

Este trabalho visa mostrar a importância da responsabilidade socioambiental nas instituições financeiras como condicionantes de práticas sustentáveis através de suas políticas de financiamento e crédito, utilizando o Banco Nacional de Desenvolvimento Econômico e Social (BNDES) como exemplo. Para tal, pretende-se responder à seguinte pergunta: como as instituições financeiras podem ser condicionantes de práticas sustentáveis através de suas políticas de financiamento e crédito?

\subsection{Objetivo}

Este trabalho pretende mostrar a importância da Responsabilidade Socioambiental nas Instituições Financeiras como indutoras e condicionantes de práticas sustentáveis, através de suas políticas de financiamento e crédito, lançando um olhar sobre a legislação existente e os mecanismos de mercado, tendo como exemplo principal o caso do BNDES.

\subsection{Relevância}

Com as mudanças que o mundo vem sofrendo devido ao consumo e produção desenfreada, é necessário que todos nós, pessoas e empresas, comecemos a ter atitudes, com vistas a um desenvolvimento mais sustentável. Com isso, as empresas, especialmente as instituições financeiras, objetos de estudo deste trabalho, precisam empregar esforços para obter práticas voltadas para o social e o ambiental, bem como influenciar o mercado como um todo. Espera-se que o resultado final do estudo possa ser interessante para incentivar as instituições financeiras a adotar ao máximo as práticas sustentáveis, impactando cada vez mais positivamente a sociedade e o meio ambiente e 
também servir para futuros estudos na área, que visem aprofundar mais este tema.

\subsection{Delimitação}

Este estudo tem como foco entender o papel das instituições financeiras como indutoras de práticas sustentáveis no mercado. Para isso, busca aprofundar-se nas estratégias, instrumentos e mecanismos existentes no mercado e na legislação. Além disso, o exemplo vai se restringir ao caso do Banco Nacional de Desenvolvimento Econômico e Social (BNDES). Ademais, haverá uma breve descrição sobre os diferentes tipos de instituições financeiras e definição do que é Responsabilidade Socioambiental e Sustentabilidade. 


\section{Referencial Teórico}

Neste tópico são apresentados e definidos os conceitos, mecanismos e políticas relacionados ao tema estudado e que servirão de base para a análise.

\subsection{Sustentabilidade}

Nas últimas décadas, a humanidade começou a pensar mais na questão da sustentabilidade, devido às grandes mudanças que estão ocorrendo no mundo (NASCIMENTO, 2012). Atualmente, "já é vista como um vetor de inovação e de criação de novos negócios ou mesmo de novos modelos de negócios" (YOSHIDA et al., 2017, p. 19). Ao longo dos séculos, o conflito entre crescimento econômico e preservação ambiental sempre esteve presente (NASCIMENTO, 2012).

No início dos tempos, o tamanho da população era bem menor. Não havia uma preocupação com as reservas de recursos não renováveis. Acreditava-se que elas eram infinitas e o consumo de energia e a produção de lixo não eram grandes. Porém, nas últimas décadas, o aumento da poluição, a degradação dos recursos naturais renováveis e não renováveis e os desastres ambientais acentuaram-se (NASCIMENTO, 2012).

Em outras palavras, podemos dizer que o nosso desenvolvimento se tornou menos sustentável, ou insustentável, pois os recursos não renováveis poderão acabar dentro de alguns anos; o consumo e o preço da energia vêm aumentando e poderão chegar num ponto em que esta se torne insuficiente para atender à demanda; e o lixo gerado viaja cada vez para mais longe (NASCIMENTO, 2012, página 16).

Dias ressalta que com a industrialização os problemas ambientais agravaram-se: "alta concentração populacional, devido à urbanização acelerada; consumo excessivo de recursos naturais, sendo que alguns não renováveis (petróleo e carvão mineral, por exemplo); contaminação do ar, do solo, das águas; e do desflorestamento, entre outros" (DIAS, 2011, p. 6).

Segundo Nascimento (2012), a partir da década de 60, o mundo começou a pensar nas questões ambientais e a ter uma maior consciência sobre elas. Podemos admitir que o marco na história da gestão ambiental foi o livro da 
autora Raquel Carson, lançado em 1962, intitulado A Primavera Silenciosa. O livro expõe as relações e conexões entre meio ambiente, economia e bem-estar social. Enquanto isso, no Brasil foram elaborados o Estatuto da Terra em 1964, o novo Código de Defesa Florestal em 1965 e a lei de Proteção à Fauna em 1967. Ademais, durante essa década, foi criado o Instituto Brasileiro de Desenvolvimento Florestal e instituídos reservas indígenas, parques nacionais e reservas biológicas.

Em 1972, o Clube de Roma ${ }^{1}$ lançou o relatório Limites ao Crescimento, alertando a sociedade sobre os riscos de um crescimento econômico desenfreado (NASCIMENTO, 2012). Assim como Nascimento (2012), Dias (2011) defende que esse crescimento desenfreado levou à destruição do meio ambiente gradativamente, pois eram usados os recursos naturais sem pensar no futuro. A contribuição deste relatório foi muito importante, pois influenciou, assim, a realização em 1972 da Conferência das Nações Unidas sobre Meio Ambiente e Desenvolvimento, em Estocolmo, na Suécia (NASCIMENTO, 2012).

A década de 70 pode ser denominada como a década da regulamentação e do controle ambiental (NASCIMENTO, 2012). Foi quando a humanidade começou a questionar-se mais sobre os recursos naturais serem limitados, sobre a deterioração ambiental e sobre o modelo de crescimento econômico utilizado, que agravou os problemas ambientais (DIAS, 2011). A Conferência de Estocolmo levou os países a estruturarem seus órgãos ambientais e a estabelecerem legislações para controlar a poluição. Após a conferência, o Brasil criou em 1973 a Secretaria Especial do Meio Ambiente (SEMA), que estabeleceria as normas e padrões de preservação do meio ambiente (NASCIMENTO, 2012). Dessa conferência resultou a Declaração sobre o Ambiente Humano, cujo objetivo era "orientar a preservação e a melhoria no ambiente humano" e o Programa das Nações Unidas sobre o Meio Ambiente (PNUMA) que foi criado para fiscalizar a progressão dos "problemas ambientais" mundiais (DIAS, 2011, p. 20).

$\mathrm{Na}$ década de 1980, foram sancionadas leis que visavam controlar a instalação de novas indústrias, bem como as emissões das indústrias já existentes. Em 1981, o Congresso Nacional aprovou a Lei no 6.938 , que implementou a Política Nacional do Meio Ambiente, transferindo para os Estados

${ }^{1}$ Grupo fundado em 1968, para debater os temas relacionados à política, economia internacional, meio ambiente e desenvolvimento sustentável. Esse grupo era formado por cientistas, educadores, industriais e funcionários públicos (DIAS, 2011). 
e Municípios a responsabilidade de proteger o meio ambiente (NASCIMENTO, 2012).

Mesmo com todas essas leis e a conscientização mundial, o foco ainda era em como resolver o problema da poluição no final do processo e não antes dela ser produzida. Além disso, na mesma época a contaminação ambiental por resíduos perigosos tornou-se um problema, como, por exemplo, o vazamento na usina nuclear de Chernobyl, em 1986, na Ucrânia, antiga União Soviética (NASCIMENTO, 2012). Esse e outros acidentes semelhantes fizeram com que o mundo tomasse conhecimento e se conscientizasse "dos problemas causados pela sua má gestão" (DIAS, 2011, p. 8).

Nesta mesma década, as empresas passaram a considerar a preservação ambiental como uma necessidade, pois auxiliava na redução do desperdício durante a produção e trazia credibilidade para a empresa (NASCIMENTO, 2012).

Segundo Nascimento (2012), no fim da década de 80, a preocupação com a conservação do meio ambiente espalhou-se pelo mundo, o que levou, por exemplo, à criação do Protocolo de Montreal em 1987, que proíbe os produtos que contenham os clorofluorcarbonos (CFC's) em sua fórmula, além de estabelecer prazos para sua substituição. Outra grande criação nessa época foi o Relatório da Comissão Mundial sobre o Meio Ambiente e Desenvolvimento (CIMAD), estabelecido pela Assembleia Geral das Nações Unidas em 1987. Esse relatório, também denominado Relatório Brundtland, foi apresentado sob o título de Nosso Futuro Comum e ajudou a disseminar globalmente o conceito de Desenvolvimento Sustentável ${ }^{2}$. Esse relatório apresenta um desenvolvimento que deve englobar tanto a questão ecológica quanto a econômica, além de mostrar que os Estados têm um papel importante, assumindo a culpa pelos danos causados ao meio ambiente e pelas políticas adotas causadoras desses danos (DIAS, 2011).

O autor, nessa mesma obra, explica que o Relatório Brundtland é um marco no que diz respeito à questão ambiental e ao desenvolvimento sustentável, pois alertou o mundo sobre a necessidade de abandonar o desenvolvimento desenfreado e adotar um mais consciente, aliando progresso econômico e preservação ambiental. Esse relatório chegou a influenciar o artigo 225 da Constituição Brasileira, publicada em 1988: "Todos têm direito ao meio ambiente ecologicamente equilibrado, bem de uso comum do povo e essencial à

\footnotetext{
2 "Desenvolvimento econômico e social que atende às necessidades do presente sem comprometer a capacidade de atendimento das gerações futuras" (MAXIMIANO, 2009, p 381).
} 
sadia qualidade de vida, impondo-se ao Poder Público e à coletividade o dever de defendê-lo e preservá-lo para as presentes e futuras gerações" (DIAS, 2011, p. 20).

Durante a década de 1990, houve uma preocupação ainda maior com o meio ambiente. Em 1992, outro marco importante da questão ambiental foi estabelecido: a Conferência das Nações Unidas sobre o Meio Ambiente e Desenvolvimento (CNUMAD), intitulada como Cúpula da Terra ou Eco-92. Dessa conferência resultou a Carta da Terra e a Agenda 21 (NASCIMENTO, 2012). Dias acrescenta que a CNUMAD chegou à conclusão de que "'a proteção ambiental constitui parte integrante do processo de desenvolvimento, (sic) e não pode ser considerada isoladamente deste'. O meio ambiente e o desenvolvimento são duas faces da mesma moeda com nome próprio, desenvolvimento sustentável, o qual não se constitui num problema técnico, mas social e político" (DIAS, 2011, p. 22 e 23).

Nascimento (2012) observa que, a partir do final do século $X X$, a questão do meio ambiente passou a ser universal, mudando assim a gestão ambiental. Passou-se a buscar a otimização completa do processo produtivo, com o objetivo de impactar o menos possível o meio ambiente. As empresas, em consequência, passaram a se preocupar mais com sua imagem e credibilidade do que só com as penalidades jurídicas. Dias conclui que, no final do século XX, houve "a formulação de uma nova estratégia de desenvolvimento que contempla o meio ambiente não mais como depositário dos restos da civilização industrial, mas como parte integrante e necessária de qualquer progresso que a humanidade queira realizar" (DIAS, 2011, p. 16), além de citar que as instituições financeiras internacionais começaram a utilizar regulamentações mais severas para induzir uma visão mais consciente sobre o meio ambiente, estabelecendo metas ambientais para liberar os recursos.

Simões et al. (2008) citam que, nessa mesma década, o conceito de responsabilidade socioambiental das organizações ganhou força devido às mudanças de pensamentos que estavam ocorrendo nas organizações, passando de uma visão estritamente econômica para uma visão mais sustentável.

Outro fato importante que aconteceu durante a década de 90, especificamente em 1992, foi a promulgação das normas britânicas BS 7750 Specification for Environmental Management Systems (Especificação para Sistema de Gestão Ambiental), que visavam criar um conjunto de normas ambientais mundiais. Essas normas integram as séries ISO 14000 e ISO 9000 
(gestão da qualidade), que visam à conservação do meio ambiente e o desenvolvimento sustentável (NASCIMENTO, 2012).

Já no século XXI, foi realizada a Conferência Rio+10 na África do Sul, cujo propósito era analisar os feitos alcançados após dez anos da Eco-92 (NASCIMENTO, 2012). Os países participantes chegaram à conclusão de que os objetivos determinados nas conferências anteriores não tinham sido alcançados e que, para alcançar o desenvolvimento sustentável, era necessário continuar buscando a proteção do meio ambiente e os desenvolvimentos econômico e social (DIAS, 2011). No Brasil foi sancionado em 2001 o Estatuto das Cidades, que tem como finalidade estimular "a reforma urbana e o combate à especulação imobiliária; a ordenação do uso e ocupação do solo urbano; e a gestão democrática da cidade". Esse estatuto possui vários artigos relacionados à gestão ambiental e à sustentabilidade (CARVALHO; BRAGA, 2001, apud NASCIMENTO, 2012, p. 22).

Nascimento (2012, p. 22) conclui que a gestão ambiental nas empresas evoluiu "de forma a, inicialmente, atender às regulamentações do setor público e, posteriormente, atender às exigências dos stakeholders e da sociedade como um todo". Adicionalmente, os dilemas ambientais passaram a ser considerados "como fator de competitividade, conquista de mercado e manutenção, em médio e longo prazo, da produção".

\subsubsection{Tripé da Sustentabilidade}

O Tripé da Sustentabilidade ou Triple Bottom Line, foi um conceito que apareceu na década de 1990, tornando-se mais conhecido em 1997, após a publicação do livro de John Elkington, Cannibals With Forks: The Triple Bottom Line of 21st Century Business. Esse conceito tem o objetivo de apresentar um "conjunto de valores, objetivos e processos em que uma organização deve focar para criar valor em três dimensões: econômica, social e ambiental" (DIAS, 2011, p. 46).

De uma forma bastante essencial, o que está em questão, quando se usa a expressão triple bottom line, é que as corporações devem ter como foco de seus interesses não somente o valor econômico que elas agregam, mas também os valores ambientais e sociais que elas adicionam, ou destroem (SIMÕES et al., 2008, p. 103).

Chamado também de 3 Ps (People, Planet e Profit), nos últimos tempos esse conceito vem ganhando cada vez mais força, com a questão de as 
empresas se preocuparem cada dia mais com a responsabilidade socioambiental e os impactos que podem ter sobre seus stakeholders. Os 3 Ps apontam que é necessário que as empresas avaliem seus resultados não só do ponto de vista econômico, mas também do social e do ambiental (DIAS, 2011).

Figura 1 Equilíbrio dinâmico da Sustentabilidade

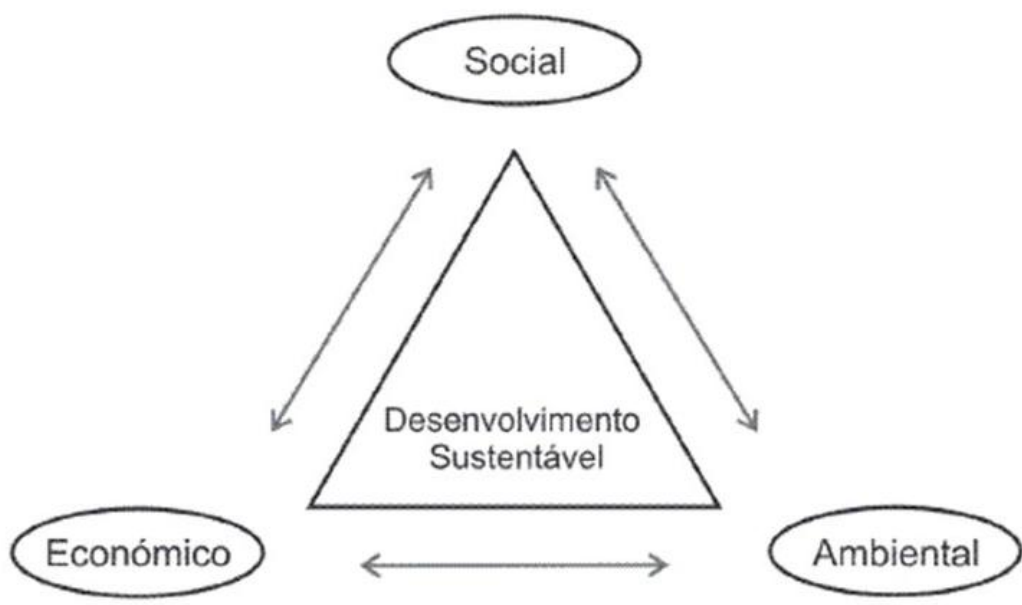

Fonte: Dias, 2011, p. 46

Os 3 Ps:

- "People (social): Refere-se ao tratamento do capital humano de uma empresa ou sociedade

- Planet (ambiental): Refere-se ao capital natural de uma empresa ou sociedade

- Profit (econômico): Trata-se do lucro. É o resultado econômico positivo de uma empresa"

(DIAS, 2011, p. 46)

\subsection{Responsabilidade Socioambiental}

Responsabilidade social empresarial é um conceito que está ligado à responsabilidade da empresa pelos impactos causados pelas suas práticas e ações. "Dizer que uma organização é responsável, nesse caso, significa que as pessoas que a ela se associam devam (sic) responder pelos próprios atos ou apelos de outrem, de forma legal ou moralmente pela vida, pelo bem-estar de alguém" (FERREIRA, 1999, apud SIMÕES et al., 2008, p. 21).

Numa proposta de compatibilizar as dimensões internalista e externalista da responsabilidade social empresarial, Melo Neto e Brennand (2004, p.5) afirmam que 
'uma empresa socialmente responsável é aquela que investe no bem-estar de seus funcionários e dependentes e no ambiente de trabalho saudável, além de preservar o meio ambiente e incentivar ações sociais' (SIMÕES et al., 2008, p. 33).

Dias (2011, p. 173) cita que são muitas as definições que se podem dar ao conceito de Responsabilidades Social Empresarial (RSE) ou Responsabilidade Social Corporativa (RSC). "Na prática, porém, o conceito de RSE, 'promove um comportamento empresarial que integra elementos sociais e ambientais que não necessariamente estão contidos na legislação mas que atendem às expectativas da sociedade em relação à empresa'”. O autor também ressalta que (p.190) "a responsabilidade ambiental está contida dentro da responsabilidade social empresarial e deve ser entendida como parte integrante desta, nunca de forma isolada".

Foi no final do século XIX que o conceito de responsabilidade social começou a ganhar mais força, pois, com as "mudanças que ocorrem na economia, na sociedade e no meio empresarial, iniciam-se os primeiros movimentos em defesa da igualdade de direitos e de oportunidades para que todas as pessoas possam desenvolver suas potencialidades, ocorrendo a inserção de uma preocupação ética no seio das ideias liberais" (p. 41). Ou seja, a questão da responsabilidade social se fortaleceu com o êxito das ideias neoliberais sobre o fracasso dos regimes ditos "socialismo real", além do aumento das demandas pela sociedade civil ("educação, saúde, cidadania, habitação, assistência social, segurança e outros") (SIMÕES et al., 2008, p. 22).

Porém, no início do século XX, surgiram manifestações contra esses novos papéis das organizações por parte de alguns empresários e acadêmicos mais conservadores, que defendiam que as organizações deveriam pensar só no lucro (TORRES, 2002, apud SIMÕES et al., 2008).

Com o aumento das demandas por parte da população e o governo não conseguindo atendê-las, foi necessário criar "uma nova solução estrutural" para enfrentar os problemas sociais. Sendo assim, as empresas passaram a adotar práticas "compromissadas com valores que não apenas os balizados pela produtividade, pela eficácia e pela eficiência do universo estritamente econômico". Através da adoção dessas práticas mais sociais e uma atitude mais ética por parte das empresas, essas passaram a ser "protagonistas diretas do desenvolvimento social" (SIMÕES et al., 2008, p. 23). 
Essas práticas inicialmente eram mais filantrópicas ${ }^{3}$, no sentindo de que a empresa passava para terceiros (ONGS) a responsabilidade de fazê-las. Depois de algum tempo, as empresas resolveram elas mesmas adotar essas práticas, ao invés de passá-las para terceiros, o que as levou "a criar e a desenvolver seus próprios projetos sociais, gerenciados por seus institutos e fundações sociais ou por departamentos e cargos criados para este fim. Surgem também parcerias de diversos matizes entre as empresas, Estado, entidades do chamado Terceiro Setor e a comunidade" (SIMÕES et al., 2008, p. 24).

As iniciativas tomadas pelas empresas foram consideradas "prioritárias para servir de indutores da inclusão social e da promoção da cidadania. É assim que o combate à exclusão social e as diversas iniciativas voltadas para a diminuição da pobreza e da miséria, o fomento da economia popular, a promoção da educação, a prevenção da criminalidade e o combate ao trabalho infantil entram para a agenda social do mundo empresarial" (SIMÕES et al., 2008, p. 24).

Segundo Maximiano (2009, p.371), é antiga a discussão sobre a responsabilidade das empresas na sociedade. Uns defendem que as empresas possuem "responsabilidades com a sociedade e devem cumpri-las", enquanto "outros pensam que a única responsabilidade das organizações empresariais é cuidar de seus acionistas". O autor defende em seu livro que há duas doutrinas acerca da responsabilidade social das empresas.

\begin{tabular}{|c|c|}
\hline $\begin{array}{c}\text { DOUTRINA DA } \\
\text { RESPONSABILIDADE SOCIAL }\end{array}$ & $\begin{array}{c}\text { DOUTRINA DO INTERESSE } \\
\text { DO ACIONISTA }\end{array}$ \\
\hline $\begin{array}{l}\text { - As organizações são instituições } \\
\text { que usam recursos da sociedade. } \\
\text { - Portanto, têm responsabilidades } \\
\text { com a sociedade. } \\
\text { O papel da empresa é aumentar a } \\
\text { riqueza da sociedade. }\end{array}$ & $\begin{array}{l}\text { - As organizações são responsáveis } \\
\text { perante seus acionistas apenas. } \\
\text { - O objetivo é maximizar o lucro do } \\
\text { acionista. } \\
\text { - A responsabilidade pelos } \\
\text { problemas da sociedade é do } \\
\text { governo e dos cidadãos. }\end{array}$ \\
\hline
\end{tabular}

Fonte: Maximiano, p. 379, 2009

A primeira doutrina tem como princípio "que as organizações são instituições sociais que existem com autorização da sociedade, utilizam os recursos da sociedade e afetam a qualidade de vida da sociedade". Já a segunda "propõe que as empresas tenham obrigações primordialmente com

3 "Doações que a empresa faz ocasionalmente não são ações de RSE; são um tipo de ajuda eventual que presta a empresa" (DIAS, 2011, p. 174). 
seus acionistas". O principal defensor dessa segunda doutrina foi Friedman (MAXIMIANO, 2009, p. 379).

Milton Friedman defendia que as empresas possuíam como responsabilidade somente maximizar os lucros dos acionistas e obedecer às leis, pois, se a empresa se preocupar com questões sociais, perde sua finalidade, podendo gerar conflitos entre os acionistas e administradores, além de perder lucro. Outras preocupações, como a questão social, são de responsabilidade do governo e da sociedade. Ou seja, Friedman defende a visão dos stockholders ("acionistas e os principais provedores de capital para as empresas, como bancos, agentes financeiros e fundos de Investimentos") (SIMÕES et al., 2008, p. 24 e 25). Além disso, Milton argumentava que "os administradores não têm condições de definir as prioridades nem as necessidades de recursos dos problemas sociais e devem concentrar-se naquilo que é fundamental para as empresas, ou seja, fazer dinheiro. A solução dos problemas sociais deve ser entregue às pessoas que se preocupam com eles e ao governo" (MAXIMIANO, 2009, p. 380).

Porém, houve questionamentos à visão defendida por Friedman. Peter Drucker foi um dos que a questionaram, defendendo a visão dos Stakeholders ${ }^{4}$, em que a empresa pode afetar ou ser afetada por agentes internos ou externos (SIMÕES et al., 2008), além de as mesmas possuírem responsabilidades com a sociedade e deverem atuar de forma a contribuir positivamente para a sociedade (MAXIMIANO, 2009).

Simões et al. (2008, p. 28) apresentam a conclusão de diversos autores no que diz respeito à responsabilidade social, como por exemplo, a visão de Carrol, que aborda a responsabilidade social sob quatro ângulos:

- "Responsabilidade econômica: maximizar o lucro para os proprietários e os acionistas; a produção de bens e serviços a preço justo; e o provimento de remuneração justa aos investidores e parceiros

- Responsabilidade Legal: obrigação em (sic) obedecer às leis, consistindo no cumprimento das obrigações legais e fiscais e na observância do disposto nas legislações federal, estadual e municipal

4 Os chamados grupos de interesse, "são todos aqueles que afetam as corporações ou são por elas afetados. Esses grupos são constituídos pelos empregados, acionistas, clientes, fornecedores, consumidores, concorrentes, comunidade, mídia e governo, ou seja, todos os públicos que, direta ou indiretamente, se relacionam com a empresa e são também chamados de atores, ou atores sociais" (SIMÕES et al., 2008, p. 25). 
- Responsabilidade Ética: assumir o compromisso de fazer o que é certo e evitar danos em qualquer esfera

- Responsabilidade Discricionária ou Filantrópica: contribuição para a comunidade e à qualidade de vida, consistindo em patrocínios, doações e financiamentos de programas, projetos e causas sociais de interesse da comunidade e da sociedade como um todo".

E chegaram à conclusão de que "a responsabilidade social é um instrumento de gestão de negócios capaz de gerar resultados e benefícios não só para a comunidade (bem-estar social), mas, sobretudo, para a empresa" (p.27).

Algumas empresas passaram efetivamente a mudar suas práticas e a estabelecer novas formas de relação com funcionários, com consumidores e com o meio ambiente. Passaram ainda a prestar contas de suas ações sociais e ambientais, buscando uma mudança na imagem diante dos consumidores, dos acionistas e da sociedade em geral. A responsabilidade social empresarial consolida-se como uma obrigação que a empresa assume com a sociedade e significa que ela deve procurar minimizar seus efeitos negativos sobre esta e maximizar os efeitos positivos (FERREL et al., 2001, p.7, apud SIMÕES et al., 2008, p. 48).

Ainda, os autores concluem que esse conceito de responsabilidade empresarial "é complexo e dinâmico e está relacionado a diferentes ideias. No entanto, enraíza-se, principalmente, na responsabilidade irrestrita das pessoas que representam as empresas pelas consequências dos impactos das operações destas sobre seu ambiente interno e externo. Esta responsabilidade é construída por meio do diálogo ético e transparente com todos os stakeholders, incorporando seus resultados à gestão empresarial na construção do desenvolvimento sustentável" (p.50).

Assim, os empresários estão se conscientizando de que a empresa não é somente uma unidade de produção e distribuição de bens e serviços que atendem a determinadas necessidades da sociedade, mas que deve atuar de acordo com uma responsabilidade social que se concretiza no respeito aos direitos humanos, na melhoria da qualidade de vida da comunidade e da sociedade mais geral e na preservação do meio ambiente natural (DIAS, 2011, p.175).

\subsubsection{Instituições financeiras}

As instituições financeiras podem ser definidas como intermediadoras entre clientes e serviços financeiros. São reconhecidas como instituições financeiras: bancos de investimento, bancos comerciais, bancos de 
desenvolvimento, bancos múltiplos, financeiras, corretora de valores, Distribuidora de Títulos e Valores Mobiliários (DTVMs), Caixa Econômica Federal, cooperativas de Crédito, instituições de microcrédito, companhias Hipotecárias, Gestoras de Recursos (Asset Managers) (BTG PACTUAL DIGITAL, 2018).

\subsection{Mecanismos obrigatórios ou regulatórios}

\subsubsection{Resolução do Conselho Monetário Nacional $\mathbf{n}^{\circ}$ 4.327/2014}

A resolução no 4.327 foi estabelecida pelo Banco Central em 2014, tendo como principal objetivo obrigar as instituições financeiras a implementar uma Política de Responsabilidade Socioambiental (PRSA), onde as mesmas possam gerenciar seus riscos, incluído os riscos socioambientais e estabelecer princípios e práticas de responsabilidade socioambiental (YOSHIDA et al., 2017).

Esta resolução estabelece dois princípios:

- Princípio da relevância: o quanto uma organização está exposta ao risco socioambiental das suas atividades e operações.

- Princípio da proporcionalidade: "compatibilidade da PRSA com a natureza da instituição e com a complexidade de suas atividades e de seus serviços e produtos financeiros"

(YOSHIDA et al., 2017, p. 39).

Essa resolução também trata da questão da estrutura de governança, pois estabelece "alguns parâmetros obrigatórios, como a designação de um diretor responsável pelo cumprimento da política; a sua divulgação interna e externa; a manutenção de documentação disponível ao Banco Central do Brasil, bem como sua avaliação quinquenal pela instituição" (YOSHIDA et al., 2017, p. 39).

\subsubsection{Normativo SARB da FEBRABAN $n^{\circ} 14 / 2014$}

Criado pelo Sistema de Autorregulação Bancária ("SARB”) da FEBRABAN, em 2014, esse normativo segue a resolução no 4.327 estabelecida pelo Banco Central em 2014. Teve como objetivo especificar com mais clareza "quais seriam efetivamente os critérios e mecanismos a serem observados pelas instituições financeiras quando da avaliação do risco ambiental dos projetos a serem 
financiados", além de definir conceitos, estabelecer diretrizes e procedimentos ligados a PRSAs e gestão dos riscos (YOSHIDA et al., 2017, p. 181).

\subsubsection{Política Nacional do Meio Ambiente $n^{\circ}$ 6.938/81}

Segundo Maximiano (2009, p. 382), a Lei da Política Nacional do Meio Ambiente, n 6.938 de 1981, é um "marco legal da proteção ambiental no Brasil", estabelecendo princípios, objetivos, ferramentas e o Estudo de Impacto Ambiental no sistema de leis.

Art $2^{\circ}$ - A Política Nacional do Meio Ambiente tem por objetivo a preservação, melhoria e recuperação da qualidade ambiental propícia à vida, visando assegurar, no País, condições ao desenvolvimento socioeconômico, aos interesses da segurança nacional e à proteção da dignidade da vida humana (BRASIL, 1981).

Neste mesmo livro (p. 382), o autor mostra alguns dos instrumentos contidos nessa lei:

- "Licenciamento ambiental: O licenciamento é 'o procedimento administrativo pelo qual o órgão ambiental competente licencia a localização, instalação, ampliação e a operação de empreendimentos e atividades utilizadoras de recursos ambientais consideradas efetiva ou potencialmente poluidoras ou daquelas que, sob qualquer forma, possam causar degradação ambiental'.

- Avaliação de impacto ambiental: o Estudo Prévio do Impacto Ambiental é exigido sempre que houver a possibilidade de significativa degradação do meio ambiente.

- Responsabilidade civil ambiental: Quem degrada o meio ambiente responde administrativa, civil e penalmente por seu ato. 'É o poluidor obrigado, independentemente de existência de culpa, a indenizar ou reparar os danos causados ao meio ambiente e a terceiros, afetados por sua atividade"'.

No que diz respeito às instituições financeiras, essa lei prevê que tais instituições devem exigir dos tomadores de crédito o licenciamento ambiental, assim como o respeito às exigências feitas pelo Conselho Nacional do Meio Ambiente (CONAMA) (YOSHIDA et al., 2017). 


\subsubsection{Licenciamento Ambiental}

O licenciamento ambiental foi instaurado na Lei da Política Nacional do Meio Ambiente, $n^{\circ} 6.938$ de 1981, porém ele foi revisado pela Resolução do CONAMA № 237 de 1997 (DIAS, 2011).

Esse Licenciamento é uma autorização fornecida pelo Órgão competente, que pode ser tanto o IBAMA quanto os órgãos estaduais ou municipais dependendo do impacto que o empreendimento pode causar, após um estudo de impacto ambiental (EIA $)^{5}$ e o Relatório de Impacto sobre o Meio Ambiente $\left(\right.$ RIMA $^{6}$ (DIAS, 2011).

Segundo Dias (2011, p. 73), impacto ambiental "pode ser definido como a modificação no meio ambiente causada pela ação do homem".

Na lei estão previstas a emissão de três licenças:

- Licença Prévia: elaboração do Termo de Referência para a realização do EIA/RIMA. Nessa fase é produzido o Relatório de Controle Ambiental, onde é descrito todo o empreendimento e as emissões que podem ser geradas. Feito isso, as obras do empreendimento são fiscalizadas e uma audiência pública é feita para ouvir todas as partes interessadas. Somente após essa audiência, pode-se obter a liberação prévia.

- Licença de Instalação: a empresa é autorizada a começar a construção, porém, se desejar fazer modificações no projeto original, deve comunicar o órgão licenciador para uma nova avaliação.

- Licença de Operação: nessa fase, o empreendimento é autorizado a funcionar. Além disso, a empresa deve se comprometer a manter os controles ambientais.

(NASCIMENTO, 2012).

\subsubsection{Princípio Poluidor-Pagador (PPP)}

Este princípio é um dos principais regulamentos do direito ambiental. Possui como objetivo obrigar a organização que poluiu a pagar pelos prejuízos que causou. $\mathrm{O}$ governo, por sua vez, fica livre de qualquer gasto com os danos

\footnotetext{
${ }^{5}$ No EIA é onde se faz a verificação dos impactos que o empreendimento pode causar e de alternativas para o mesmo (DIAS, 2011).

${ }^{6}$ O Relatório de Impacto Ambiental é o resumo das conclusões obtidas no EIA (DIAS, 2011).
} 
causados pela empresa ou na recuperação das áreas poluídas. Esse conceito surgiu em 1972, na Organização para a Cooperação e Desenvolvimento Económico (OECD), organização que definiu o principio afirmando que "o poluidor deve arcar com os custos de controle de poluição e medidas de prevenção exigidas pela autoridade pública, independentemente se (sic) estes (sic) custos são (sic) o resultado da imposição de alguma taxa de poluição, ou se é (sic) debitado (sic) por algum outro mecanismo econômico satisfatório, ou ainda, se é (sic) uma resposta a algum regulamento direto de redução de poluição obrigatória" (DIAS, 2011, p.49).

No Brasil, esse princípio foi adotado na Política Nacional de Meio Ambiente no 6.938, de 31 de agosto de 1981, no artigo 4º e na Constituição Brasileira de 1988, no artigo 225, 2ำ parágrafo (DIAS, 2011).

A lei no 6938/81, no seu artigo 12, trata da questão das instituições financeiras também serem responsabilizadas junto com os tomadores do crédito pelos danos causados ao meio ambiente (YOSHIDA et al., 2017).

\subsubsection{Lei Anticorrupção n 12.846/2013}

A Lei Anticorrupção foi criada em 2013, sendo um importante avanço na questão do combate à corrupção. Essa lei estabelece "a possibilidade de a pessoa jurídica responder objetivamente, no âmbito civil e administrativo, independente de culpa, por atos que atentem contra o patrimônio público nacional ou estrangeiro" (YOSHIDA et al., 2017, p.109).

\subsubsection{Lei dos Crimes contra o meio ambiente no $9.605 / 98$}

A Lei dos Crimes contra o meio ambiente, $n^{0}$ 9.605, foi sancionada em 1998. Dessa lei, originou-se o estabelecimento de três órgãos para auxiliar na preservação do meio ambiente (MAXIMIANO, 2009).

São eles:

- "Conselho Nacional do Meio Ambiente (Conama): Órgão consultivo e deliberativo, cuja missão principal é assessorar, estudar e propor diretrizes de políticas ambientais, bem como deliberar sobre normas e padrões de controle ambiental.

- Ministério do Meio Ambiente.

- Instituto Brasileiro do Meio Ambiente e dos Recursos Naturais Renováveis (Ibama): Órgão executor da política e das diretrizes federais do meio ambiente". 
Essa lei "dispõe sobre as sanções penais e administrativas derivadas de condutas e atividades lesivas ao meio ambiente" (BRASIL, 1998).

\subsubsection{Política Nacional sobre Mudança do Clima $\mathrm{n}^{\circ}$ 12.187/2009}

Instaurada em 2009, a Lei da Política Nacional sobre Mudança do Clima (PNMC) no 12.187 tem como objetivo reduzir as emissões de gases do efeito estufa até 2020, "buscando garantir que o desenvolvimento econômico e social contribua para a proteção do sistema climático global" (BRASIL, 2009).

Segundo Yoshida et al. (2017, p. 49), essa lei, em seu artigo $8^{\circ}$, institui a obrigatoriedade das instituições financeiras de disponibilizar "linhas de crédito e financiamento específicas para desenvolver ações e atividades que atendam aos objetivos desta Lei e voltadas para induzir a conduta dos agentes privados à observância e execução da PNMC, no âmbito de suas ações e responsabilidades sociais".

\subsubsection{Criação do Fundo Nacional sobre Mudança do Clima Lei no 12.114/2009}

Criada em 2009, essa é a lei que estabelece o Fundo Nacional sobre Mudança do Clima (FNMC). Ela foi criada com o intuito de "assegurar recursos para apoio a projetos ou estudos e financiamento de empreendimentos que visem à mitigação da mudança do clima e à adaptação à mudança do clima $\mathrm{e}$ seus efeitos". Esta lei foi regulamentada pelo decreto $n^{\circ} 7.343 / 2010$ (BNDES, 2009).

\subsubsection{Lei no 12.305/2010: Política Nacional de Resíduos Sólidos}

A Política Nacional de Resíduos Sólidos (PNRS) foi estabelecida pela Lei n $12.305 / 10$, cujo objetivo é "a prevenção e a redução na geração de resíduos, tendo como proposta a prática de hábitos de consumo sustentável e um conjunto de instrumentos para propiciar o aumento da reciclagem e da reutilização dos resíduos sólidos (aquilo que tem valor econômico e pode ser reciclado ou reaproveitado) e a destinação ambientalmente adequada dos rejeitos (aquilo que não pode ser reciclado ou reutilizado)" (BRASIL, 2010). 
Em seu artigo 18으, essa lei determina financiamentos e incentivos a projetos e empreendimentos que possuam como objetivo solucionar os problemas dos resíduos sólidos (YOSHIDA et al., 2017).

\subsubsection{Código Florestal: Artigo78-A Lei no $12.651 / 2012$}

Criada em 2012, a Lei n 12.651 sobre o Código Florestal instituiu "normas gerais sobre a Proteção da Vegetação Nativa, incluindo Áreas de Preservação Permanente, de Reserva Legal e de Uso Restrito; a exploração florestal, o suprimento de matéria-prima florestal, o controle da origem dos produtos florestais, o controle e prevenção dos incêndios florestais, e a previsão de instrumentos econômicos e financeiros para o alcance de seus objetivos" (BRASIL, 2012a).

Essa lei também estabeleceu o Cadastro Ambiental Rural (CAR), que obrigará o cadastramento de todos os imóveis rurais nesse sistema do governo, e o Programa de Regularização Ambiental (PRA), que auxiliará os produtores rurais a recompor as áreas degradadas de suas propriedades (BRASIL, 2012a).

Outra questão abordada nessa lei foi a determinação às instituições financeiras de conceder somente "crédito agrícola, em qualquer de suas modalidades, para proprietários de imóveis rurais que estejam inscritos no CAR" (YOSHIDA et al., 2017, p. 49).

\subsubsection{Decreto n $6.961 / 2009$}

O Decreto ํ 6.961, estabelecido em 2009, institui o "zoneamento agroecológico da cana-de-açúcar e determina ao Conselho Monetário Nacional o estabelecimento de normas para as operações de financiamento ao setor sucroalcooleiro, nos termos do zoneamento" (YOSHIDA et al., 2017, p. 50).

\subsubsection{Resoluções no 3.813/2009 e no 3.814/2009}

As resoluções no 3.813 e 3.814 , ambas de 2009, possuem como objetivo condicionar "o crédito rural e o crédito agroindustrial para expansão da produção e industrialização da cana-de-açúcar ao Zoneamento Agroecológico e vedam o financiamento da expansão do plantio nos Biomas Amazônia e Pantanal e Bacia do Alto Paraguai, entre outras áreas" (YOSHIDA et al., 2017, p. 50). 


\subsubsection{Decreto $n \div 6.321 / 2017$}

O Decreto $n^{\circ} 6.321$ de 2017, dispõe "sobre ações relativas à prevenção, controle e monitoramento do desmatamento ilegal no bioma Amazônia. Inserido nos esforços para estancar o desmate ilícito na Amazônia, tal decreto buscou integrar vários órgãos do governo e entidades do setor econômico para o alcance de seus objetivos" (YOSHIDA et al., 2017, p.62).

\subsubsection{Decreto nำ $6.514 / 2008$}

Instituído em 2008, o Decreto no 6.514 trata "das infrações e sanções administrativas ao meio ambiente, além de estabelecer o processo administrativo federal para apuração das penalidades" (YOSHIDA et al., 2017, p.63). Algumas dessas sanções são: a perda de financiamentos e contratações com entidades públicas e perdas de licenças obtidas para funcionar (YOSHIDA et al., 2017).

\subsubsection{Resolução no $3.545 / 2008$}

A Resolução no 3.545 foi estabelecida pelo Conselho Monetário Nacional em 2008, "dispondo sobre documentos exigíveis pelas instituições financiadoras aos beneficiários do crédito rural no bioma Amazônia" (YOSHIDA et al., 2017, p.64). Essa resolução determina que sejam exigidos: "(i) documento que comprove a regularidade ambiental do imóvel para o qual se pleiteia o crédito (licença, certificado, certidão ou outro instrumento comprobatório), (ii) Certificado de Cadastro de imóvel Rural - CCIR e (iii) declaração de inexistência de embargos de atividades na propriedade" (YOSHIDA et al., 2017, p.64).

\subsubsection{Lei de Acesso à Informação no 12.527/2011}

A Lei de Acesso a Informação foi sancionada em 2011. Seu objetivo é regulamentar a obrigação dos órgãos e instituições públicas a divulgar suas informações, por ser um "direito constitucional de acesso dos cidadãos às informações públicas. É aplicável aos três Poderes da União, dos Estados, do Distrito Federal e dos Municípios" (BNDES, 2011).

Essa lei foi regulamentada pela Lei de Acesso à informação $n^{0}$ 7.724/2012 (BRASIL, 2012). 


\subsubsection{Lei no $10.743 / 2003$}

A Lei $n^{\circ} 10.743$ aprovada em 2003, "institui no Brasil o Sistema de Certificação do Processo de Kimberley - SCPK, relativo à exportação e à importação de diamantes brutos, e dá outras providências" (BRASIL, 2003).

\subsubsection{Lei de Responsabilidade das Estatais no 13.303/2016}

A Lei de Responsabilidade das Estatais $\mathrm{n}^{0} 13.303$ foi promulgada em 2016, estabelecendo "regras mais rígidas para compras, licitações e para a nomeação de diretores, membros do conselho de administração e de presidentes em empresas públicas e de sociedade mista" (BRASIL, 2016).

Essa Lei foi regulamentada pela Lei n`8.945/2016 (BRASIL, 2016a).

\subsubsection{Circular BACEN no 3.678/2013}

A circular $n^{\circ}$ 3.678, foi emitida pelo BACEN em 2013 e determina que as instituições financeiras divulguem "informações referentes à gestão de riscos, à apuração do montante dos ativos ponderados pelo risco (RWA) e à apuração do Patrimônio de Referência (PR)" (BRASIL, 2013).

\subsection{Mecanismos existentes no mercado}

\subsubsection{Pacto Global}

Lançado em 2000, o Pacto Global, desenvolvido pelo ex-secretário da ONU Kofi Annan, visa estimular o comprometimento das empresas com práticas mais sustentáveis e inclusivas, envolvendo os temas relacionados aos direitos humanos, condições de trabalho, meio ambiente e combate à corrupção. O Pacto fundamenta-se na Declaração Universal de Direitos Humanos, Declaração da Organização Internacional do Trabalho sobre Princípios e Direitos Fundamentais no Trabalho, Declaração do Rio sobre Meio Ambiente e Desenvolvimento e Convenção das Nações Unidas Contra a Corrupção (SIMÕES et al., 2008).

O Pacto conta com a participação da Agência das Nações Unidas, empresas, sindicatos, organizações não governamentais, entre outros. Este não é um instrumento de regulamentação, mas sim uma iniciativa voluntária, tendo como principal proposta direcionar as empresas a contribuir para uma economia 
global inclusiva e sustentável, adotando os valores da responsabilidade social e ajudando no fortalecimento de outros atores sociais (SIMÕES et al., 2008).

Figura 2 Os dez princípios do Pacto Global
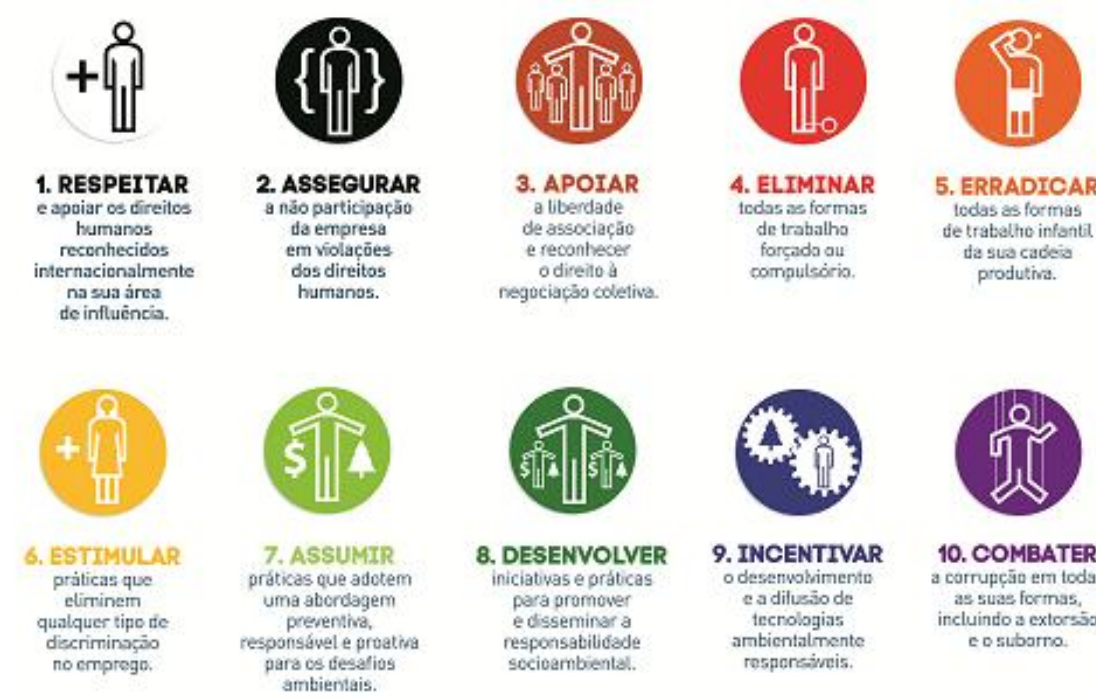

4. ELIMINAR

tedas as formas
de trabalho

forçado ou

5. ERRADICAR

tedas as formas

de trabalho infont:

ta sua cadeia
produtiva.

odireilo a

compulsórin.

Fonte: Rede Brasil do Pacto Global, 2018.

Segundo Simões et al. (2008), por ser uma iniciativa das Nações Unidas, o Pacto Global resultou em inúmeros projetos sociais, parcerias e alianças. De acordo com o Instituto Ethos, sua maior contribuição foi levar o conceito de responsabilidade social corporativa a países que ainda não tinham conhecimento dessas novas ações empresariais. Entretanto, ainda há críticas ao pacto, devido a uma parte da sociedade considerar que ele pode facilitar muitas empresas multinacionais a vincular seu nome à ONU sem que atestem atuações concretas de responsabilidade socioambiental. Além do mais, não estão previstas sanções nem inspeções nas empresas por parte das Nações Unidas.

\subsubsection{Objetivos de Desenvolvimento Sustentável}

Em 2015, a Organização das Nações Unidas lançou 17 objetivos de desenvolvimento sustentável (ODS), também conhecidos como Objetivos Globais, durante a Cúpula de Desenvolvimento Sustentável, cujos principais temas são: Social, Ambiental, Econômico e Institucional. Esses objetivos visam induzir e conscientizar toda a sociedade a um desenvolvimento sustentável, diminuindo assim a pobreza, promovendo a prosperidade, o bem-estar e protegendo o meio ambiente. Esses objetivos fazem parte da Agenda 2030, que visa atingir nos próximos 15 anos a paz universal, a erradicação da pobreza e o desenvolvimento sustentável. Os países signatários e partes interessadas irão 
atuar em parceria para implementar os objetivos dessa Agenda (ORGANIZAÇÃO DAS NAÇÕES UNIDAS, 2018).

Esses objetivos foram construídos a partir do legado dos Objetivos de Desenvolvimento do Milênio (ODM) das Nações Unidas, criados em 2000, que possuíam como objetivo melhorar a vida dos mais necessitados. Os ODS visam concluir o que os ODM não conseguiram atingir, levando em consideração as dimensões do desenvolvimento sustentável, ou seja, a parte econômica, social e ambiental (YOSHIDA et al., 2017).

Os Objetivos de Desenvolvimento Sustentável são a primeira agenda mundial no que diz respeito ao desenvolvimento sustentável e isso convida todas as nações a agir em seus próprios territórios (YOSHIDA et al., 2017).

Figura 3: Objetivos de Desenvolvimento Sustentável
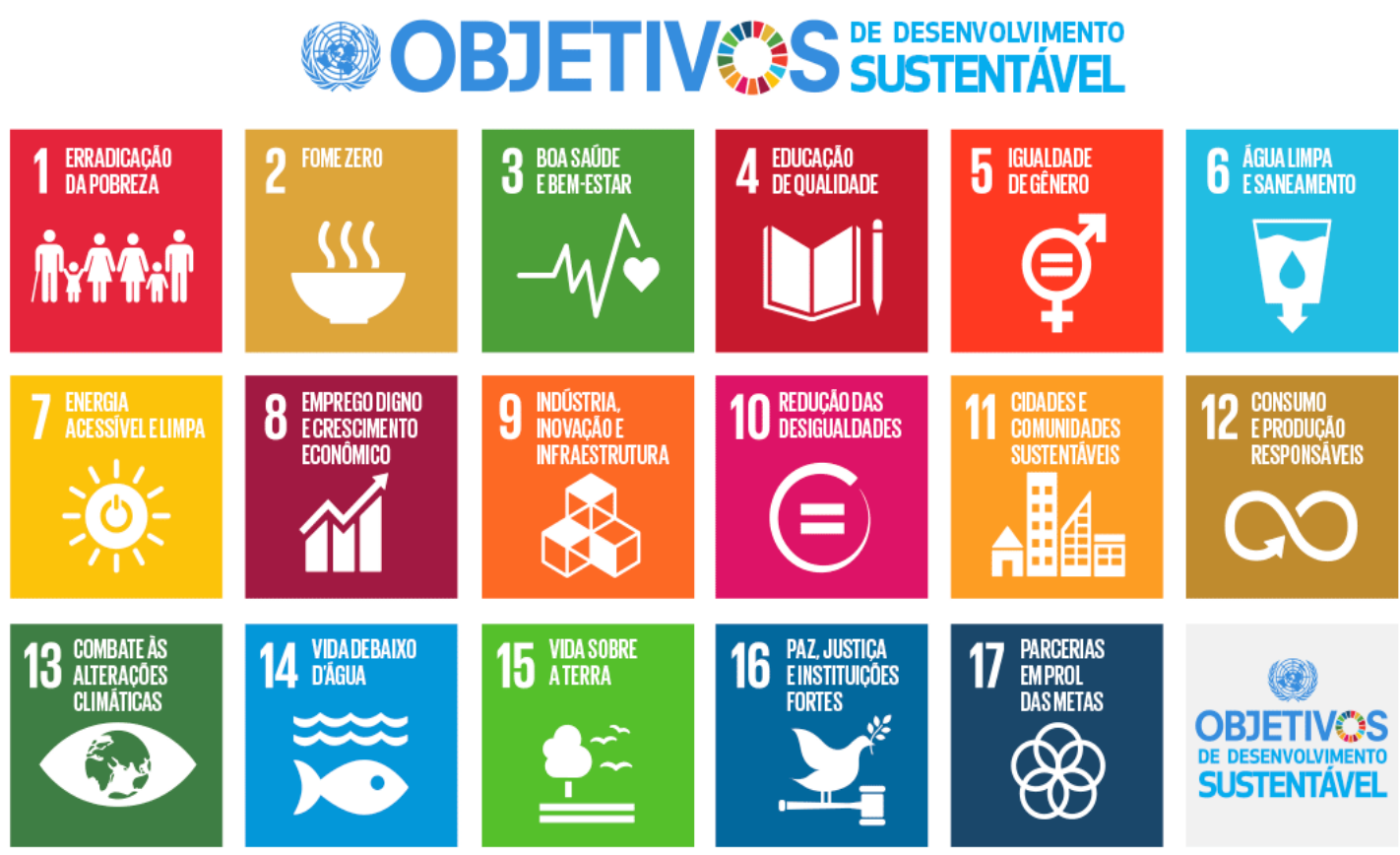

Fonte: Organização das Nações Unidas - 2018.

\subsubsection{Agenda 21}

A Agenda 21 foi lançada em 1992 durante a Conferência nas Nações Unidas sobre o Meio Ambiente e Desenvolvimento Humano, mais conhecida como Eco-92. Essa agenda, "é um programa de ações para o qual contribuíram governos e instituições da sociedade civil de 179 países, o que constitui a mais ousada e abrangente tentativa já realizada de promover, em escala planetária, um novo padrão de desenvolvimento, conciliando métodos de proteção ambiental, justiça social e eficiência econômica" (NASCIMENTO, 2012, p.46). 
Tem como objetivo ajudar os países participantes a elaborar e implementar uma Agenda própria, visando: "preservar as florestas e as nascentes, buscar substitutos para o CFC e outras substâncias que destroem a camada de ozônio, proibir a pesca destrutiva, buscar novas fontes de energia renováveis, reduzir o lixo produzido e encontrar combustíveis alternativos" (NASCIMENTO, 2012, p.48).

\subsubsection{Princípios do Equador}

Os princípios do Equador surgiram depois da Rio+10 em 2002, quando a International Finance Corporation (IFC) ou Corporação Financeira Internacional, se reuniu com os dez maiores bancos de financiamento mundiais ${ }^{7}$, visando criar "critérios mínimos ambientais e de responsabilidade social que devem ser atendidos para a concessão de créditos" (DIAS, 2011, p. 17). Esses Princípios se aplicam a operações superiores "a US\$10.000.000,00 (dez milhões de dólares americanos), ou Financiamentos Corporativos Dirigidos a Projetos (PRCL) de pelo menos US\$50.000.000,00 (cinquenta milhões de dólares americanos)" (CALDAS; MARTINS, 2016, p. 191).

Lançado oficialmente em 2003, os Princípios do Equador é um sistema desenvolvido para gerenciar os riscos, onde as instituições financeiras podem "determinar, avaliar e gerenciar riscos ambientais e sociais em projetos" (ASSOCIAÇÃO DOS PRINCÍPIOS DO EQUADOR, 2018a). Dias (2011, p. 175) cita que "a adesão dos bancos é voluntária, e as operações de crédito devem receber notas que variam de $A$ a $C$, sendo que os classificados com notas $A$ e $B$ são considerados de alto e médio riscos, respectivamente".

- Categoria A:

- Efeitos negativos altos

- "Situações em que os efeitos ambientais possam ser significativamente adversos ou irreversíveis, ao afetar grupos étnicos ou minoritários, envolver deslocamento de populações ou impactar sobre comunidades tradicionais ou patrimônios histórico-culturais significativos".

- Deve-se exigir uma avaliação ambiental (como, por exemplo, o EIA - Estudos de Impacto Ambiental) que

7 São eles: ABN Amro, Barclays, Citigroup, Crédit Lyonnais, Crédit Suisse, HypoVereinsbank (HVB), Rabobank, Royal Bank of Scotland, WestLB e Westpac. Esses representam "mais de $30 \%$ do total de investimentos em todo o mundo" (COMPÊNDIO PARA A SUSTENTABILIDADE, 2018). 
contenha tanto os efeitos negativos quanto os positivos, além de mostrar outras alternativas "viáveis e recomendar medidas para prevenir, minimizar, mitigar ou compensar impactos adversos e melhorar a performance ambiental".

- Categoria B:

- Efeitos negativos médios.

- "Situações em que os impactos ambientais em populações ou habitats naturais podem ser considerados menos severos, sendo passível prevenir os danos ou risco de danos".

- Os impactos podem ser sentidos somente no território afetado.

- Pode-se adotar "medidas mitigadoras" buscando evitar tais impactos ou caso ocorram que possam ser "minimizados" os efeitos.

- Categoria C:

- Efeito negativo muito pequeno ou nenhum

○ "Não é exigido nenhum tipo de avaliação ambiental e tampouco medidas mitigadoras específicas."

Fonte: Caldas e Martins, 2016, p. 192 e 193.

Quando uma instituição adere aos princípios, ela compromete-se a desenvolver "políticas, procedimentos e práticas socioambientais individuais e internas", "procedimentos e padrões para financiar projetos" e deixarão de financiar projetos que impactem negativamente o meio ambiente e a sociedade (ASSOCIAÇÃO DOS PRINCÍPIOS DO EQUADOR, 2018a).

Em 2013, os Princípios do Equador foram "redimensionados e atualizados, sendo, portanto, intitulados Princípios do Equador III", adicionando "novos temas e áreas de desenvolvimento", com o intuito de continuar conservando os Princípios do Equador como uma referência nas questões socioambientais, "permitindo à instituição financeira o apoio responsável e controlado ao risco gerado pelo empreendimento" (CALDAS; MARTINS, 2016, p. 190 e 191).

Segundo Caldas e Martins (2016, p. 194), os Princípios serviram de base para a criação da Resolução no 4.327/2014 do Banco Central brasileiro, Normativo no 14, de 2014, do Sistema de Autorregulação Bancária (SARB) da Federação Brasileira de Bancos (FEBRABAN) e de auxiliou no estabelecimento de "uma Política de Responsabilidade Socioambiental (PRSA) que deve 
englobar não só os mecanismos de avaliação ambiental, mas também um sistema de governança voltado para os aspectos socioambientais, incrementado o grau de segurança das operações financeiras, notadamente dos empréstimos relativos a projetos de infraestrutura".

Atualmente, 97 bancos internacionais adotam os Princípios do Equador (ASSOCIAÇÃO DOS PRINCÍPIOS DO EQUADOR, 2018b). Entre esses, os bancos brasileiros são: Banco Bradesco S.A., Banco do Brasil, Caixa Econômica Federal, Banco Itaú Unibanco e Banco Votorantim S.A. (YOSHIDA et al., 2017).

\subsubsection{Protocolo Verde}

O Protocolo Verde ${ }^{8}$ surgiu em 1995, quando o Governo Federal e os bancos brasileiros firmaram um acordo que integrava a variável ambiental na gestão e concessão de crédito e benefícios fiscais, visando criar artifícios que impedissem a utilização destes créditos e benefícios em atividades e projetos que fossem nocivos ao meio ambiente (DIAS, 2011).

Fizeram parte do grupo que instituiu esse protocolo os representantes do Ministério do Meio Ambiente, dos Recursos Hídricos e da Amazônia Legal, do Ministério da Agricultura, do Abastecimento e da Reforma Agrária, do Ministério da Fazenda, do Ministério do Planejamento e Orçamento, do Instituto Brasileiro do Meio Ambiente e dos Recursos Naturais Renováveis, do Banco Central do Brasil, do Banco Nacional de Desenvolvimento Econômico e Social, do Banco do Brasil, da Caixa Econômica Federal, do Banco do Nordeste do Brasil e do Banco da Amazônia. Sua iniciativa está também prevista na Política Nacional do Meio Ambiente (DIAS, 2011).

Os cinco bancos participantes do grupo divulgaram um documento intitulado Carta de Princípios para o Desenvolvimento Sustentável, onde se comprometeram com o desenvolvimento sustentável. Abaixo, a íntegra da carta:

CARTA DE PRINCÍPIOS PARA O DESENVOLVIMENTO SUSTENTÁVEL

${ }^{8}$ Segundo o portal Pensamento Verde (2013), as instituições financeiras possuem um papel muito importante, pois elas podem "auxiliar na promoção da recuperação e proteção do meio ambiente, por meio de linhas de financiamento específicas. Privilegiando, assim, o financiamento de projetos que não sejam agressivos ao meio ambiente ou que apresentem características de sustentabilidade". 
Os bancos abaixo assinados reconhecem que podem cumprir um papel indispensável na busca de um desenvolvimento sustentável que pressuponha uma contínua melhoria no bem-estar da sociedade e da qualidade do meio ambiente. Para tanto, propõem-se a empreender políticas e práticas bancárias que estejam sempre e cada vez mais em harmonia com o objetivo de promover um desenvolvimento que não comprometa as necessidades das gerações futuras. Princípios Gerais do Desenvolvimento Sustentável:

1. A proteção ambiental é um dever de todos que desejam melhorar a qualidade de vida no planeta e extrapola qualquer tentativa de enquadramento espaço-temporal.

2. Um setor financeiro dinâmico e versátil é fundamental para o desenvolvimento sustentável.

3. O setor bancário deve privilegiar de forma crescente 0 financiamento de projetos que não sejam agressivos ao meio ambiente ou que apresentem características de sustentabilidade.

4. Os riscos ambientais devem ser considerados nas análises e nas condições de financiamento.

5. A gestão ambiental requer a adoção de práticas que antecipem e previnam degradações do meio ambiente.

6. A participação dos clientes é imprescindível na condução da política ambiental dos bancos.

7. As leis e regulamentações ambientais devem ser aplicadas e exigidas, cabendo aos bancos participar da sua divulgação.

8. A execução da política ambiental nos bancos requer a criação e treinamento de equipes específicas dentro dos seus quadros.

9. A eliminação de desperdícios, a eficiência energética e o uso de materiais reciclados são práticas que devem ser estimuladas em todos os níveis operacionais.

10. Os princípios aqui assumidos devem constituir compromisso de todas as instituições financeiras.

(DIAS, 2011, p. 48).

Em 2009, através da Federação Brasileira de Bancos (FEBRABAN), os bancos privados ${ }^{9}$ assinaram protocolo de intenções com o Ministério do Meio Ambiente, aderindo assim ao Protocolo Verde (DIAS, 2011).

Segundo o protocolo, os financiamentos só deverão ser liberados para empresas que visem desenvolver políticas socioambientais, como, por exemplo, respeito aos direitos humanos e trabalhistas, preservação da biodiversidade, valorização da diversidade das culturas locais, redução da pobreza e da desigualdade na distribuição de renda. Também, as empresas ou pessoas tomadoras do crédito não poderiam ter dívidas com o IBAMA, do contrário não poderiam receber o empréstimo e teriam seus nomes incluídos no Cadastro de

${ }^{9}$ Segundo uma reportagem do jornal O Estadão de São Paulo(2009), alguns dos bancos privados que aderiram são: Itaú Unibanco, Santander Brasil, Bradesco, entre outros. 
Inadimplentes do Banco Central (Cadin), impedindo-as de fazer transações com instituições financeiras governamentais ou de participar de concorrências públicas (DIAS, 2011).

\subsubsection{GRI - Global Reporting Initiative}

Criada em 1997, a Global Reporting Initiative surgiu de uma parceria entre a Geres (Coalition for Environmentally Responsible Economies) e o Programa Ambiental das Nações Unidas, cujo objetivo principal é desenvolver e disseminar globalmente diretrizes, visando a elaboração de relatórios voluntários de sustentabilidade pelas organizações que desejam divulgar o conteúdo e o impacto de suas atividades, produtos e serviços (SIMÕES et al., 2008).

O GRI é uma ferramenta que possibilita avaliar a política de sustentabilidade corporativa e sua efetiva realização. Possui 11 princípios transparência, inclusividade, auditabilidade, completude, relevância, contexto de sustentabilidade, exatidão, neutralidade, comparabilidade, clareza e conveniência - que estipulam condutas baseadas em critérios de transparência e prestação de contas, com base nas dimensões econômica, ambiental e social da sustentabilidade. Suas diretrizes fazem uso de indicadores distribuídos nessas dimensões (SIMÕES et al., 2008). São exemplos desses indicadores:

- "Econômicos: salários e benefícios, produtividade do trabalho, criação de empregos, despesas em pesquisa e desenvolvimento, investimentos em treinamento e outras formas de capital humano;

- Ambientais: impactos de processos, produtos e serviços no ar, na água, na terra, na biodiversidade e na saúde humana;

- Sociais: saúde e segurança no ambiente de trabalho, retenção de funcionários, direitos dos trabalhadores, direitos humanos, salários e condições de trabalho"

(SIMÕES et al., 2008).

Segundo Simões et al. (2008), o GRI possui potencialidade na aplicação da responsabilidade socioambiental nas empresas. Conta com o apoio de empresas e organizações não governamentais mundiais, obtendo a participação de representantes da área de negócios, contabilidade, investimentos, meio ambiente, direitos humanos, pesquisas e organizações trabalhistas. Incentiva as empresas a estabelecer metas e relatar os resultados obtidos. Se as metas estabelecidas não forem alcançadas no prazo proposto, a mesma deverá se explicar, o que a torna mais comprometida com o processo. 
Apesar disso, apontam-se limitações ao GRI, como uma maior dificuldade de aplicação em empresas de menor porte, pelo fato de suas diretrizes focarem inicialmente as grandes empresas, além de a iniciativa não prever verificação externa de avaliação da consistência dos resultados obtidos, não garantindo, assim, credibilidade nas informações dos relatórios produzidos pelas empresas (SIMÕES et al., 2008).

Os autores destacam que, apesar de não haver vínculo formal, o GRI complementa o Pacto Global, pois tenta converter seus princípios em algo mensurável e aplicável às empresas que o adotam. Seus relatórios permitem que pessoas externas à empresa, principalmente investidores e sociedade civil, avaliem e acompanhem como as empresas estão implementando os dez princípios do Pacto Global (SIMÕES et al., 2008).

\subsubsection{Indicadores Ethos de responsabilidade social}

O Instituto Ethos de Empresas e Responsabilidade Social é uma OSCIP (Organização da Sociedade Civil de Interesse Público), criada em 1998 por empresários e executivos da iniciativa privada (INSTITUTO ETHOS, 2012).

O Instituto Ethos, desenvolveu indicadores de responsabilidade social para auxiliar as empresas a incorporar a sustentabilidade e a responsabilidade social empresarial (RSE) em suas estratégias de negócio. As empresas de pequeno, micro ou grande porte podem aderir voluntariamente aos indicadores Ethos (INSTITUTO ETHOS, 2012a).

Segundo o Instituto Ethos, esta ferramenta é formada por um questionário que contempla perguntas que podem ser analisadas tanto do ponto de vista qualitativo quanto do quantitativo, possibilitando o autodiagnóstico da gestão da empresa, e um sistema de preenchimento on-line, que proporciona a obtenção de relatórios, permitindo fazer o planejamento e a gestão de metas para alcançar RSE/Sustentabilidade (INSTITUTO ETHOS, 2012a).

Essa ferramenta será aprimorada continuamente e apresenta uma abordagem nova para a gestão das empresas, além de procurar integrar os princípios e comportamentos da RSE com os objetivos para a sustentabilidade (INSTITUTO ETHOS, 2012a).

Os indicadores são separados em 7 temas:

- "Valores, transparência e governança - indicadores: Autorregulação e Conduta, Relações transparentes com a sociedade;

- Público interno - indicadores: Diálogo e participação, Respeito ao indivíduo, Trabalho decente; 
- Meio ambiente - indicadores: Responsabilidade com as gerações futuras, Gerenciamento do impacto ambiental;

- Fornecedores - indicadores: Seleção, Avaliação e Parceria com fornecedores;

- Consumidores e clientes - indicadores: Dimensão social do consumo;

- Comunidade - indicadores: Relações com a comunidade local, Ação social;

- Governo e sociedade - indicadores: Transparência política, Liderança social"

(SIMÕES et al., 2008, p. 142 à 144).

O instituto Ethos em parceria com a Febraban, publicaram em 2003, os Indicadores Setoriais Ethos-Febraban de Responsabilidade Social Empresarial, destinados às instituições financeiras. Esse indicador setorial deve ser respondido junto com os Indicadores Ethos de Responsabilidade Social Empresarial, o que "permitirá que a empresa tenha, além de seu relatório de desempenho padrão, um segundo relatório, que considera as questões setoriais e indica como a empresa está em relação ao seu setor de atuação" (INSTITUTO ETHOS, 2008). Esses indicadores são separados em:

- "Valores, transparência e governança: Compromissos Éticos; Governança Corporativa; Diálogo e Engajamento das Partes Interessadas; Balanço Social.

- Público interno: Política de Remuneração, Benefícios e Carreira; Cuidados com Saúde, Segurança e Condições de Trabalho; Compromisso com o Desenvolvimento Profissional e a Empregabilidade.

- Meio ambiente: Compromisso com a Melhoria da Qualidade Ambiental; Educação e Conscientização Ambiental.

- Fornecedores: Apoio ao Desenvolvimento de Fornecedores

- Consumidores e clientes: Política de Comunicação Comercia; Excelência no Atendimento; Conhecimento e Gerenciamento dos Danos Potenciais dos Produtos e Serviços.

- Comunidade: Gerenciamento do Impacto da Empresa na Comunidade de Entorno; Relações com Organizações Locais.

- Governo e sociedade: Construção da Cidadania pelas Empresas; Práticas Anticorrupção e Antipropina."

(INSTITUTO ETHOS, 2008).

\subsubsection{Fundos e títulos verdes de investimento}

Segundo a Febraban (2016), os títulos verdes ou Green Bonds "são títulos de dívida usados para captar recursos com o propósito de implantar ou refinanciar projetos e compra de ativos capazes de trazer benefícios ao meio 
ambiente ou ainda contribuir para amenizar os efeitos das mudanças climáticas". Além disso, esses títulos são utilizados mais para financiamentos de longo prazo, com vistas a "estimular e viabilizar iniciativas e tecnologias com adicionalidades ambientais positivas nos diferentes tipos de organização e também para atrair investidores institucionais".

Essa Federação reconhece como títulos verdes:

- Cotas de Fundos de Investimento em Direitos Creditórios (FIDC)

- Debêntures

- Debêntures incentivadas de infraestrutura

- Letras Financeiras (LF)

- Notas promissórias

- Certificado de Recebíveis do Agronegócio (CRA)

- Certificado de Recebíveis Imobiliários (CRI)

(FEBRABAN - FEDERAÇÃO BRASILEIRA DE BANCOS, 2016)

\subsubsection{UNEP Finance Initiative (UNEP-FI)}

Lançado em 1992 durante a Conferência das Nações Unidas sobre o Meio Ambiente e Desenvolvimento (CNUMAD), o Programa das Nações Unidas para o Meio Ambiente - Iniciativa Financeira (UNEP-FI) "é uma parceria entre a Organização das Nações Unidas para o Meio Ambiente e o setor financeiro global", com o objetivo "de promover finanças sustentáveis" (PROGRAMA DAS NAÇÕES UNIDAS PARA O MEIO AMBIENTE - INICIATIVA FINANCEIRA, 2017).

A UNEP-FI possui mais de 200 instituições financeiras (bancos, seguradoras e investidores) como membros, trabalhando em conjunto "para entender os desafios ambientais, sociais e de governança de hoje, por que eles são importantes para financiar e como participar ativamente para lidar com eles". As instituições brasileiras que participam são: Banco Bradesco S.A., Banco Itaú Holding Financeira S.A., Banco Nacional de Desenvolvimento Econômico e Social (BNDES), Brasilcap Capitalização S.A, Caixa Seguradora S.A., Grupo Segurador Banco do Brasil e Mapfre, Itaú Seguros S.A, Liberty Seguros S/A, Mongeral Aegon Seguros e Previdência S.A., Porto Seguro S.A., Seguradora Líder DPVAT, Sulamérica, Terra Brasis Resseguros S.A. (PROGRAMA DAS NAÇÕES UNIDAS PARA O MEIO AMBIENTE - INICIATIVA FINANCEIRA, 2017a). 
As instituições que aderem a UNEP-FI devem assinar uma declaração de compromisso, onde "reconhecem abertamente o papel do setor de serviços financeiros de tornar nossa economia e estilos de vida sustentáveis e se comprometem com a integração de considerações ambientais e sociais em todos os aspectos de suas operações" (PROGRAMA DAS NAÇÕES UNIDAS PARA O MEIO AMBIENTE - INICIATIVA FINANCEIRA, 2017).

Essa iniciativa visa o "fornecimento de pesquisa técnica e orientação sobre ferramentas e práticas bancárias sustentáveis, liderando e apoiando iniciativas de liderança, trabalhando com membros e especialistas para desenvolver novos conceitos, metodologias e abordagens e promovendo diálogo político e engajamento" (PROGRAMA DAS NAÇÕES UNIDAS PARA O MEIO AMBIENTE - INICIATIVA FINANCEIRA, 2017).

\subsection{9. Índice de Sustentabilidade Dow Jones (DJSI WORLD)}

O índice de Sustentabilidade Dow Jones, lançado em 1999, tem como objetivos avaliar o desempenho de sustentabilidade das 2500 maiores empresas do Índice de Mercado de Valores Global da Dow Jones e questões relacionadas a governança corporativa, gerenciamento de risco, branding, mitigação de mudanças climáticas, cadeias de suprimentos e práticas de trabalho. Esse índice se baseia no Tripé da Sustentabilidade e tornou-se referência para os investidores em investimentos sustentáveis (YOSHIDA et al., 2017).

Para serem inseridas neste índice, as corporações são julgadas e escolhidas conforme seus planos de longo prazo de gestão econômicos, sociais e ambientais. Os critérios de seleção são aprimorados a cada ano e as empresas devem buscar aperfeiçoamento contínuo em seus planos de sustentabilidade para poder permanecer no índice (YOSHIDA et al., 2017).

\subsubsection{International Finance Corporation (IFC)}

A International Finance Corporation ou Corporação Financeira Internacional pertence ao Banco Mundial e "é a maior instituição de desenvolvimento global voltada para o setor privado nos países em desenvolvimento" (CORPORAÇÃO FINANCEIRA INTERNACIONAL, 2017a).

A IFC foi criada em 1956 e possui ao todo 184 países membros, tendo atuação em mais de 100 países. Possui como principais objetivos:

\footnotetext{
- "Fortalecer o enfoque nos mercados fronteiriços
} 
- Abordar a mudança climática e assegurar a sustentabilidade

- Abordar as restrições ao crescimento do setor privado em infraestrutura, saúde, educação e na cadeia de suprimentos alimentares

- Desenvolver mercados financeiros locais

- Criar relacionamentos de longo prazo com clientes de mercados emergentes"

(CORPORAÇÃO FINANCEIRA INTERNACIONAL, 2017c).

A IFC faz parcerias com governos, corporações, fundações, organizações e instituições de desenvolvimento e financiamento, visando melhorar o desenvolvimento da sociedade. Ela auxilia seus clientes a gerir seus riscos ambientais, sociais e de governança corporativa, através de padrões de desempenho fornecidos por ela, que são referências mundiais para o setor financeiro. São eles:

- "Padrão de Desempenho 1: Avaliação e Gestão de Riscos e Impactos Socioambientais

- Padrão de Desempenho 2: Condições de Emprego e Trabalho

- Padrão de Desempenho 3: Eficiência de Recursos e Prevenção da Poluição

- Padrão de Desempenho 4: Saúde e Segurança da Comunidade

- Padrão de Desempenho 5: Aquisição de Terra e Reassentamento Involuntário

- Padrão de Desempenho 6: Conservação da Biodiversidade e Gestão Sustentável de Recursos Naturais Vivos

- Padrão de Desempenho 7: Povos Indígenas

- Padrão de Desempenho 8: Patrimônio Cultural"

(CORPORAÇÃO FINANCEIRA INTERNACIONAL, 2012d).

A IFC ajuda os clientes a evitar, mitigar e gerenciar os riscos ambientais, sociais e de governança como forma de fazer negócios de maneira sustentável. Nossa Estrutura de Sustentabilidade e a Metodologia de Governança Corporativa ajudam nossos clientes a melhorar o desempenho de seus negócios, aumentar a transparência, envolver as pessoas afetadas por nossos investimentos, proteger o meio ambiente $e$ alcançar maior impacto no desenvolvimento (CORPORAÇÃO FINANCEIRA INTERNACIONAL, 2018b).

\subsubsection{1.Índice de Sustentabilidade Empresarial da Bolsa de Valores de São Paulo (ISE-BOVESPA)}

O índice de Sustentabilidade Empresarial da Bolsa de Valores de São Paulo foi criado em 2005, com os objetivos de promover um espaço de investimento ligado à demanda de desenvolvimento sustentável e incentivar a responsabilidade ética das empresas através de boas práticas (YOSHIDA et al., 
2017). Foi uma iniciativa pioneira na América Latina e inicialmente foi financiada pela Corporação Financeira Internacional (IFC), braço financeiro do Banco Mundial (ÍNDICE DE SUSTENTABILIDADE EMPRESARIAL, 2017).

O índice de Sustentabilidade BOVESPA é uma ferramenta que compara o desempenho das empresas listadas na $\mathrm{B}^{10}{ }^{10}$, sob o ponto de vista da sustentabilidade do negócio, "baseada em eficiência econômica, equilíbrio ambiental, justiça social e governança corporativa. Também amplia o entendimento sobre empresas e grupos comprometidos com a sustentabilidade, diferenciando-os em termos de qualidade, nível de compromisso com o desenvolvimento sustentável, equidade, transparência e prestação de contas, natureza do produto, além do desempenho empresarial nas dimensões econômico-financeira, social, ambiental e mudança do clima" (ÍNDICE DE SUSTENTABILIDADE EMPRESARIAL, 2017).

O ISE disponibiliza uma opção de carteira formada por ações de empresas que possuem comprometimento com as questões sociais e a sustentabilidade. Esse índice adota o conceito do tripé da sustentabilidade, que leva em consideração as dimensões econômicas, sociais e ambientais, acrescentando critérios e indicadores de governança corporativa (YOSHIDA et al., 2017).

Figura 4 Carteira 2018 ISE

\begin{tabular}{|c|c|c|c|c|c|}
\hline AES Tiete & CCR & CPFL & Engie & Klabin & Latura \\
\hline B2W & Celesc & Duratex & Fibria & Santander \\
\hline Banco do Brasil & Cemig & Ecorodovias & Fleury & Lojas Americanas & Telefônica \\
\hline Bradesco & Cielo & EDP & Itaú Unibanco & Lojas Renner & Tim \\
\hline Braskem & Copel & Eletropaulo & Itaúsa & MRV & Weg \\
\hline
\end{tabular}

Fonte: ISE 2017.

Pode-se destacar a participação de alguns bancos nessa carteira do ISE, como o Banco do Brasil, Bradesco, Itaú Unibanco e Santander.

\subsubsection{Gestão Ambiental}

Sistema de Gestão Ambiental (SGA) ou Environmental Management System - EMS, "é definido como o conjunto de procedimentos que irão ajudar a organização a planejar, organizar, controlar e diminuir os impactos ambientais de

10 Companhia criada da união entre a BM\&FBOVESPA e a Cetip, que possui um portfólio variado de produtos e serviços financeiros (BM\&FBOVESPA, 2016b). 
suas atividades, produtos e/ou serviços". O sistema visa auxiliar as empresas a identificar seus pontos fracos e a tomar medidas para solucioná-los (NASCIMENTO, 2012, p. 105).

É a gestão cujo objetivo é conseguir que os efeitos ambientais não ultrapassem a capacidade de carga do meio onde se encontra a organização, ou seja, obter-se um desenvolvimento sustentável (DIAS, 2011, p. 102).

Segundo Nascimento (2012), o sistema de gestão ambiental tem como objetivos cumprir as leis ambientais e auxiliar as empresas a cada vez mais melhorar seu desempenho nas questões ambientais.

O autor no mesmo livro cita que esse sistema de gestão é um dos primeiros passos para conseguir a certificação ISO 14001.

\subsubsection{Normas ISO - International Standardization Organization}

A International Organization for Standardization (ISO) ou Organização Internacional de Normalização, é uma organização composta por 130 países. Está dividida em 180 Comitês Técnicos (TCs) especializados, cada qual elaborando normas relacionadas à sua área. A formulação dessas normas visa "facilitar o comércio internacional, aumentando a confiabilidade e a eficácia das mercadorias e serviços", através da padronização dos produtos. Com a padronização dos produtos e processos, há "uma redução de custos em função do aumento da escala de produção," o que pode ser uma vantagem para os produtores (NASCIMENTO, 2012, p. 102 e 103).

\subsubsection{ISO 14000}

Lançada em 1996, a série de normas ISO 14000 visa padronizar os sistemas de gestão ambiental. Quando uma empresa consegue uma certificação ISO, "seus produtos e serviços, passam a ser reconhecidos internacionalmente, distinguindo-se daquelas organizações que somente atendem à legislação ambiental". Além disso, as normas que pertencem à série ISO 14000 "também estabelecem as diretrizes para as auditorias ambientais, avaliação de desempenho ambiental, rotulagem ambiental e análise do ciclo de vida dos produtos", levando assim a uma maior transparência da empresa, em relação às questões ambientais (NASCIMENTO, 2012, p. 103). 
Segundo Simões et al. (2008), essa norma tem como objetivo auxiliar a organização a criar uma política ambiental, a estipular metas e objetivos, que devem ser implementados e monitorados, visando a responsabilidade ambiental da organização.

No Brasil, essa série de normas em vez de começar pela sigla ISO, é iniciada pela sigla NBR da ABNT, que cuida dessas normas no Brasil (NASCIMENTO, 2012).

Segundo Nascimento (2012, p. 107), para que uma organização consiga a certificação ambiental, ela deve cumprir três requisitos da norma ISO 14001:

- "Ter implantado um Sistema de Gestão Ambiental

- Cumprir a legislação ambiental aplicável ao local da instalação

- Assumir um compromisso com a melhoria contínua de seu desempenho ambiental"

Esse mesmo autor (p. 108) conclui que a ISO 14000 "por ser um sistema de normalização abrangente, protege àquelas (sic) organizações que respeitam as leis e os princípios da conservação ambiental, além de universalizar conceitos e procedimentos, sem perder de vista características e valores regionais. Porém, também pode ser utilizado somente como um mecanismo de vantagem competitiva comercial, uma vez que as normas não ditam como a organização deve alcançar suas metas, não descrevem o tipo de desempenho exigido e nem determinam quais os resultados a serem atingidos nos (sic) processos, focandose somente nos processos necessários para alcançar os resultados".

\subsubsection{SA 8000 - Social Accountability 8000}

Normatização estabelecida desde 1997, a Social Accountability 8000 (SA 8000), foi desenvolvida por uma organização não governamental nos EUA, a SAI (Social Accountability International) (SIMÕES et al., 2008).

A Norma SA8000 é a principal norma de certificação social para fábricas e organizações à escala global. Consiste numa estrutura abrangente que ajuda as organizações certificadas a demonstrar a sua dedicação ao tratamento justo dos trabalhadores nos vários setores e em qualquer país (SOCIAL ACCOUNTABILITY INTERNATIONAL (SAI), 2018).

Teve como base a Declaração Universal dos Direitos do Homem, acordos de Defesa dos Direitos da Criança e do Adolescente, resoluções da Organização Internacional do Trabalho (OIT), as ISO 9001 e 14001, "além de se 
basear na legislação do país onde a empresa estiver estabelecida" (SIMÕES et al., 2008, p. 179).

Simões et al. (2008) citam que, quando uma empresa adere à SA 8000, pode escolher entre duas opções: "fazer negócios apenas com fornecedores que sejam certificados na SA 8000" ou contratar "um auditor reconhecido para a obtenção da certificação". Para obter e garantir a certificação, a empresa deve buscar sempre cumprir as normas requisitadas (SIMÕES et al., 2008, p. 180).

Os mesmos autores (p. 180) mencionam que essa normatização se assimila às normas da ISO em relação "à utilização de um sistema de gestão que inclui definição da política da empresa, planejamento, elaboração e implantação da documentação (manual, procedimentos, instruções e registros), verificação de não conformidades e implantação de ações corretivas e preventivas, auditorias internas e a auditoria de certificação".

A SA 8000 é dividida em nove quesitos:

- "Trabalho infantil

- Trabalho forçado e compulsório

- Saúde e segurança

- Liberdade de associação e reivindicações coletivas

- Discriminação

- Práticas disciplinares

- Horas de trabalho

- Remuneração

- Sistemas de gestão"

(SOCIAL ACCOUNTABILITY INTERNATIONAL (SAI), 2018)

\subsubsection{ABNT NBR 16001:2004 - Responsabilidade Social - Sistema de gestão}

Elaborada pela Associação Brasileira de Normas Técnicas (ABNT) em 2004, a norma NBR 16001 tem como objetivo "estabelecer requisitos mínimos relativos a um sistema de gestão da responsabilidade social". A adesão é voluntária. Porém, quando a empresa ganha a certificação, ela mostra para a sociedade que "respeita a norma de responsabilidade social" (SIMÕES et al., 2008, p. 181 e 182). Em 2012, a norma foi atualizada baseando-se nas diretrizes da ISO 26000 (INSTITUTO NACIONAL DE METROLOGIA, QUALIDADE E TECNOLOGIA, 2004).

Essa norma auxilia as organizações a formular e a implementar "políticas e objetivos que abrangem exigências legais, compromissos éticos, transparência, cidadania e desenvolvimento sustentável das atividades de uma organização" (SIMÕES et al., 2008, p. 183). 
Essa NBR determina que, ao desenvolver as metas e objetivos da organização, essas devem incluir os onze temas ligados à Responsabilidade Social, sendo eles: responsabilização (accoutability), transparência, comportamento ético, respeito pelos interesses das partes interessadas (stakeholders), atendimento aos requisitos legais e outros requisitos subscritos pela organização (cumprimento da lei e outros requisitos), respeito pelas normas internacionais de comportamento e direito humanos (INSTITUTO NACIONAL DE METROLOGIA, QUALIDADE E TECNOLOGIA, 2004).

\subsubsection{ISO 26000 - Diretrizes em Responsabilidade Social}

Lançada em 2010, a ISO 26000 é uma norma internacional de Diretrizes de Responsabilidade Social. Qualquer empresa pode aderir voluntariamente (INSTITUTO NACIONAL DE METROLOGIA, QUALIDADE E TECNOLOGIA, 2010).

Segundo a ISO 26000 , a responsabilidade social se expressa pelo desejo e pelo propósito das organizações de incorporar considerações socioambientais em seus processos decisórios e a responsabilizar-se pelos impactos de suas decisões e atividades na sociedade e no meio ambiente. Isso implica um comportamento ético e transparente que contribua para 0 desenvolvimento sustentável, que esteja em conformidade com as leis aplicáveis e seja consistente com as normas internacionais de comportamento. Também implica que a responsabilidade social esteja integrada em toda a organização, seja praticada em suas relações e leve em conta os interesses das partes interessadas (INSTITUTO NACIONAL DE METROLOGIA, QUALIDADE E TECNOLOGIA, 2010).

Essa norma serve de guia para as organizações implementarem um sistema de gestão de responsabilidade social, não oferecendo assim nenhuma certificação ou selo (SIMÕES et al., 2008).

A ISO 26000 é dividida em sete temas principais, onde as organizações devem priorizar as questões mais relevantes para si. Os temas são:

- "Governança organizacional

- Direitos humanos

- Práticas trabalhistas

- Meio ambiente

- Práticas leais de operação

- Questões dos consumidores

- Envolvimento e desenvolvimento da comunidade" 


\subsubsection{Carbon Disclosure Project (CDP)}

Carbon Disclosure Project é uma organização sem fins lucrativos que visa intermediar oportunidades de negócios que são resultantes do aquecimento global. É composta de um questionário on-line, criado por investidores e encaminhado às empresas listadas nas principais bolsas de valores do mundo, desejando obter informações sobre suas políticas de mudanças climáticas. Só em 2014, mais de 5000 empresas responderam ao questionário sobre mudanças climáticas, água e floresta. Os dados coletados auxiliam investidores e governos a avaliar os processos de mitigação de riscos do uso de energia e recursos naturais e constatar oportunidades de investimentos sustentáveis (YOSHIDA et al., 2017). 


\section{Metodologia}

Neste capítulo são apresentadas as diferentes etapas contidas no trabalho, o método escolhido para a pesquisa, como foi feita a coleta de dados, sua análise e as limitações do estudo.

Segundo Vergara (2012, p.253), "pesquisa é um processo de aprendizagem permanente. O pesquisador é sempre um aprendiz. É a humildade intelectual que deve ser própria de um aprendiz que mitiga suas hesitações e suas incertezas, e que fecunda suas interpretações e reflexões acerca do objeto de estudo, face à teoria que o orientou e ao método que utilizou".

\subsection{Método de pesquisa utilizado}

Segundo Alyrio (2009, p. 100), "Método pode ser definido como: conjunto de regras, de normas, para busca de uma verdade, para detecção de erros na tentativa de alcançar uma finalidade desejada".

O método de pesquisa escolhido foi do tipo qualitativo descritivo. Alyrio (2009, p. 130) destaca Tesch (1990), apud Moreira (2006), que definiram esse tipo de pesquisa como uma que "trabalha predominantemente com dados qualitativos, isto é, a informação coletada pelo pesquisador não é expressa em números, ou então as conclusões neles baseadas representam um papel menor na análise". Adicionalmente, segundo Prodanov e Freitas (2013, p. 52), a pesquisa descritiva é "quando o pesquisador apenas registra e descreve os fatos observados sem interferir neles. Visa a descrever as características de determinada população ou fenômeno ou o estabelecimento de relações entre variáveis". Alyrio (2009, p. 58) acrescenta que "na pesquisa descritiva se busca essencialmente a enumeração e a ordenação de dados, sem o objetivo de comprovar ou refutar hipóteses exploratórias".

Para dar materialidade ao trabalho, utilizaremos o exemplo concreto do Banco Nacional de Desenvolvimento Econômico e Social - BNDES, analisando seus mecanismos e políticas de responsabilidade socioambiental.

A utilização do caso concreto do BNDES não tem a finalidade de explicar totalmente o tema aqui estudado, todavia dado o porte e a relevância deste 
Banco para o setor produtivo e financeiro em nosso país, serve como exemplo concreto e um forte indício sobre a relevância do tema e ferramentas para o setor financeiro.

\subsection{Procedimentos e instrumentos de coleta de dados utilizados no estudo}

Os dados utilizados são secundários, que, segundo Tachizawa e Mendes (1999, p. 41), "são aqueles obtidos, por exemplo, de obras bibliográficas ou de relatórios de pesquisas anteriores sobre o tema".

Os dados foram coletados através de levantamentos bibliográficos em sites da Internet e da própria instituição, livros, publicações, jornais e artigos.

\subsection{Análise dos dados coletados para o estudo}

A abordagem qualitativa foi adotada para analisar os dados. Esse tipo de análise "é o estudo de um objeto, buscando interpretá-lo em termos do seu significado“, não utilizando métodos estatísticos. Esse tipo de análise considera, ainda, mais o ponto de vista do pesquisador. "O objetivo é considerar a totalidade, e não dados ou aspectos isolados" (ALYRIO, 2009, p. 108).

Assim, foi realizado um cruzamento das informações obtidas do BNDES e foram observados e destacados a legislação pertinente, os mecanismos de mercado e políticas adotadas pelo banco.

\subsection{Limitações do Estudo}

Ao utilizar uma pesquisa qualitativa, torna-se comum nos depararmos com informações imprecisas, além do que, não se pode generalizar as informações obtidas para todos os casos. Pelo fato de o pesquisador fazer a interpretação dos dados e informações específicas do tema estudado e do enfoque e os limites do mesmo, a análise também pode acabar sendo influenciada por seu ponto de vista (CRESWEU, 2007).

Além disso, como o tema da responsabilidade socioambiental nas instituições financeiras ainda é um tema relativamente novo nos estudos de administração e gestão existe certa dificuldade para a obtenção de dados e informações. 


\section{Apresentação e análise dos resultados}

Este capítulo está dividido em três partes: o primeiro item faz uma apresentação do BNDES; o segundo mostra os mecanismos obrigatórios ou regulatórios; e o último, os mecanismos do mercado.

\subsection{Banco Nacional de Desenvolvimento Econômico e Social}

O Banco Nacional de Desenvolvimento Econômico e Social (BNDES) foi criado em 1952, com o objetivo de "ser o órgão formulador e executor da política nacional de desenvolvimento econômico". Inicialmente, o Banco não possuía em seu nome o $\mathrm{S}$ de social. Suas políticas eram voltadas mais para a infraestrutura, industrialização e agropecuária (BNDES, 2016b).

Nos anos 80, o Banco passou a integrar a questão social na sua política de desenvolvimento, passando a acrescentar o S de social em seu nome. Em 1993, com a questão social e ambiental em alta, o banco passou "a adotar a classificação de risco ambiental dos projetos" (BNDES, 2016b).

Foi somente no século XXI que o banco adotou em sua missão a questão social, buscando promover, assim, "competitividade da economia brasileira, de forma agregada à sustentabilidade, à geração de emprego e renda e à redução das desigualdades sociais e regionais. O BNDES busca promover, nos projetos que solicitam apoio, o desenvolvimento e a capacidade de inovação, desafios mais urgentes em um mundo cada vez mais dinâmico e em constante transformação" (BNDES, 2016b).

O BNDES é um banco público e "atua por meio de produtos, programas e fundos", com "foco no impacto socioambiental e econômico no Brasil" através de financiamentos de longo prazo (BNDES, 2017).

Incentivar a inovação, o desenvolvimento regional e o desenvolvimento socioambiental são prioridades para a instituição (BNDES, 2017).

O banco possui como missão "Viabilizar soluções financeiras que adicionem investimentos para o desenvolvimento sustentável da nação brasileira" e visão: "Tornar o Brasil um país desenvolvido até 2035 e ser 
reconhecido como o banco de desenvolvimento sustentável do Brasil pela sua relevância e efetividade" (BNDES, 2018e).

O banco possui políticas que representam "temas valorizados pela instituição", são elas:

- "Política de Dinamização Regional (PDR): promover o desenvolvimento das regiões, reduzindo as desigualdades regionais e sociais de renda.

- Política de Atuação no Entorno de Projetos: promover as oportunidades de desenvolvimento econômico e social nas áreas de influência de projetos, por meio do apoio coordenado a ações e investimentos de natureza diversa.

- Política de Atuação no Apoio à Inovação: fomentar e financiar projetos de investimento associados à formação de capacitações e de ambientes inovadores, contribuindo para o melhor posicionamento competitivo das empresas e o aumento das atividades inovativas no país, a fim de que sejam realizadas em caráter sistemático.

- Política de Atuação em Renda Variável: atuar nas operações de renda variável realizadas pelo BNDESPAR, que deverão ter como objetivo o fortalecimento da estrutura de capital de empresas brasileiras, a promoção das melhores práticas de gestão, governança e sustentabilidade, o desenvolvimento do mercado de capitais brasileiro e a criação de valor para a carteira de valores mobiliários da BNDESPAR.

- Política Socioambiental: promover o desenvolvimento sustentável, de forma proativa e em todos os empreendimentos apoiados, considerando a concepção integrada das dimensões econômica, social, ambiental e regional".

(BNDES, 2018d).

\subsection{Mecanismos Obrigatórios ou regulatórios}

Desde 2010, o BNDES estabeleceu uma Política de Responsabilidade Social e Ambiental (PRSA), que continha princípios e diretrizes que serviram de base para suas ações. Com o lançamento da Resolução do Conselho Monetário Nacional 4.327 em 2014, o banco atualizou sua PRSA, para alinhar-se com as diretrizes estabelecidas pela Resolução. Em 2014, foi instaurado o Comitê de Sustentabilidade Socioambiental (CSS), cujo objetivo era coordenar e "promover a integração das dimensões social e ambiental nas políticas, processos, práticas e procedimentos da instituição, em linha com a PRSA". Além disso, o Comitê criou um "plano plurianual de ações voltado para promover avanços progressivos na implementação da PRSA da instituição, em especial no que se refere à governança do tema, à gestão do risco socioambiental e a processos de diálogo e prestação de contas com as partes interessadas". Este plano foi aprovado em 
2015 com duração até 2017, com o nome de "Plano Plurianual de Implementação e Monitoramento da PRSA". O plano possui atualização a cada triênio, "visando direcionar e mobilizar esforços em prol de aprimoramentos na atuação socioambiental do BNDES". No fim de 2017, houve a preparação de um novo plano para o período de 2018-2020 (BNDES, 2017c). A implementação desse plano ajuda a reforçar "a missão do BNDES de promover o desenvolvimento sustentável e permite aprimorar o papel exercido pela instituição na indução de comportamentos social e ambientalmente responsáveis no meio empresarial" (BNDES, 2017c).

O Plano de Implementação e Monitoramento da Política de Responsabilidade Social e Ambiental está dividido em cinco partes:

- "Frente 1: Alinhamento Estratégico e Gestão da Implementação da Política: fortalecimento da governança no tema sustentabilidade

- Frente 2: Diálogo e Prestação de Contas: melhorias e inovação em processos e atividades de diálogo e prestação de contas (transparência, comunicação e prestação de contas à sociedade)

- Frente 3: Atuação Finalística: aprimoramento da gestão de risco e indução do desempenho socioambiental nas atividades relacionadas ao processo de concessão de apoio financeiro

- Frente 4: Liderança, Cultura e Aprendizado: fortalecimento da cultura de sustentabilidade no BNDES

- Frente 5: Administrativo-Organizacional: incorporação pelo BNDES de conceitos relacionados à sustentabilidade em suas atividades operacionais e instalações"

(BNDES, 2018a).

Em sua Política Socioambiental, o banco estabelece "instrumentos, diretrizes e procedimentos operacionais" para auxiliar em um desenvolvimento mais sustentável e a financiar projetos que realmente tenham impactos positivos para o país (BNDES, 2016c).

No cumprimento da sua Política Socioambiental, o BNDES entende que seu apoio financeiro deve conciliar sua Política Operacional com o atendimento da legislação aplicável e, no exercício de seu papel de agente de mudanças, induzir a adoção de melhores práticas socioambientais (BNDES, 2016c).

As diretrizes estabelecidas na sua Política Socioambiental são:

- "Atuar alinhado com as políticas públicas e legislações vigentes no Brasil, em especial com o disposto na Política Nacional de Meio Ambiente e, no exterior, com as legislações aplicáveis em cada país.

- Desenvolver e aperfeiçoar permanentemente produtos financeiros, metodologia, instrumentos de análise, de 
monitoramento e de avaliação que incorporem critérios socioambientais à luz de referências nacionais ou internacionais.

- Oferecer, quando couber, condições diferenciadas de apoio financeiro para empreendimentos com adicionalidades socioambientais e para empreendimentos que equacionem passivos ambientais.

- Considerar o trato das dimensões social e ambiental como questão estratégica na análise de concessão do apoio financeiro, na gestão de ativos e na análise de risco de beneficiários e de empreendimentos.

- Observar as recomendações e restrições do zoneamento ecológico-econômico e do zoneamento agroecológico, quando for o caso.

- Apoiar empreendimentos agropecuários e de silvicultura relacionados à abertura de novas áreas, somente quando em consonância com o zoneamento ecológico-econômico.

- Observar os impactos do apoio do BNDES no emprego e considerar suas políticas relativas aos direitos humanos.

- Promover nos empreendimentos apoiados a ecoeficiência, a adoção de processos e produtos social e ambientalmente sustentáveis, o uso de sistemas de gestão para toda a cadeia produtiva e a redução das emissões de gases do efeito estufa (GEE).

- Promover e orientar a adoção de ações preventivas e mitigadoras de impactos sociais e ambientais adversos.

- Ampliar e atualizar permanentemente informações sobre os padrões de impacto e desempenho socioambiental, energético e de emissão de GEE dos principais setores econômicos, bem como sobre a evolução das rotas tecnológicas e inovações.

- Ampliar e atualizar permanentemente o conhecimento sobre desenvolvimento sustentável e responsabilidade social e ambiental e compartilhar informações e experiências com beneficiários, instituições financeiras e outras organizações, buscando o diálogo e promovendo a integração de esforços para fortalecer 0 trato das dimensões social e ambiental como questão estratégica".

(BNDES, 2016c).

$\mathrm{Na}$ parte operacional, o BNDES utiliza os instrumentos abaixo, "para implementar, monitorar, avaliar e atualizar sua Política Socioambiental". São eles:

- "Produtos, linhas, programas e fundos reembolsáveis e não reembolsáveis para apoio financeiro.

- Resoluções setoriais, políticas específicas e outros normativos.

- Procedimentos internos de avaliação de risco e de análise social e ambiental de beneficiários e de empreendimentos.

- Metodologias de avaliação de beneficiários, de avaliação de risco de crédito e de monitoramento e avaliação de impacto dos empreendimentos apoiados".

(BNDES, 2016c). 
Antes da autorização do financiamento, são observados: "as legislações aplicáveis; normas setoriais específicas; a política de responsabilidade social e ambiental dos beneficiários; a regularidade ambiental; o risco ambiental do empreendimento; e práticas socioambientais que elevem o patamar de competitividade das organizações e dos setores econômicos e contribuam para a melhoria de indicadores sociais e ambientais dos empreendimentos e do país" (BNDES, 2016c).

O banco também pode:

- "Recomendar a reformulação do projeto.

- Ofertar recursos para reforço das medidas mitigadoras.

- Estimular a realização de investimentos sociais e ambientais voltados para o âmbito interno (funcionários e cadeia de fornecedores) e externo (desenvolvimento local, sociedade e meio ambiente) dos beneficiários.

- Não conceder o apoio financeiro em face da não conformidade ou do risco social e ambiental".

(BNDES, 2016c).

Durante a análise do projeto, o banco exige das empresas tomadoras do crédito as licenças ambientais estabelecidas na Política Nacional do Meio Ambiente, lei n 6.938/81, além de verificar se seguem as leis relacionadas às questões socioambientais e fiscais. Caso as empresas não apresentem essas licenças ambientais, o banco não fornece o financiamento. Dependendo do setor e segmento, como, por exemplo, os setores pecuários bovino, de açúcar e álcool, de geração elétrica e de mineração, o banco exige que os empreendimentos adotem parâmetros socioambientais e sigam as legislações específicas do setor ou segmento (BNDES, 2017e). Abaixo vão ser apresentados alguns critérios socioambientais exigidos para os setores citados acima:

- Pecuária bovina:

- "As empresas frigoríficas e de abate de animais precisam comprovar, por exemplo, que seus fornecedores não estão condenados por invasão de terras indígenas, por discriminação ou por trabalho infantil ou escravo.

- Devem se comprometer a manter a lista de seus fornecedores atualizada e verificar o cumprimento das regras por parte deles, para acompanhamento da regularidade ambiental da cadeia de fornecimento.

- De acordo com informações divulgadas pelos órgãos oficiais competentes, não ter sido condenado, o fornecedor direto ou seus dirigentes, por: invasão de terras indígenas de domínio da União (art.20 da Lei 4947/66); sentença penal envolvendo conflitos agrários; quaisquer atos que caracterizem a falsidade ou violência na obtenção de título de posse ou propriedade de terras públicas ou privadas 
(grilagem); infrações penais relativas a desmatamento (Lei 9.605/98)".

(BNDES, 2016f).

- Apresentar os documentos exigidos na Lei no 3.545/2008, como por exemplo, o Certificado de Cadastro de Imóvel Rural (CCIR) e "declaração de que inexistem embargos vigentes de uso econômico de áreas desmatadas ilegalmente no imóvel" (BNDES, 2014).

- Se o Banco observar, que as empresas tomadoras do crédito descumpriram um dos critérios estabelecidos, o mesmo dispõe de decretos como os de no 6.321/2007 e no 6.514/2008, para penalizar tais empresas (BNDES, 2014).

- Açúcar e Álcool

- "Apresentar declaração na qual ateste que o plantio, a renovação e o custeio da cultura de cana-de-açúcar, conforme o caso, ocorrem e ocorrerão integralmente em áreas permitidas pelo Decreto no 6.961, de 17.09.2009, e pelas Resoluções do Conselho Monetário Nacional (CMN) no 3.813 e 3.814 , de 26.11.2009.

- Manter cadastro atualizado de todas as propriedades próprias, arrendadas ou objeto de parceria onde a proponente realize o projeto, contemplando as seguintes informações, como condição prévia para a contratação e durante toda a vigência do contrato: nome do imóvel; município e unidade da federação onde se situa a propriedade rural; ponto georreferenciado da propriedade rural; número de inscrição da propriedade rural no Sistema Nacional de Cadastro Rural ${ }^{11}$; e número da licença ambiental, documento equivalente ou a comprovação da dispensa de licenciamento pelo órgão ambiental competente."

(BNDES, 2017f).

- Geração elétrica

- "Sistema de combustão - Usinas que utilizam carvão importado ou nacional: carvão pulverizado supercrítico ou leito fluidizado ou gaseificação integrada com ciclo combinado.

- Equipamentos para controle das emissões - Combinação dos equipamentos que forem necessários para 0 atendimento dos padrões de emissão máximos: dessulfurizadores, queimadores de baixo Nox, desnitrificadores e equipamentos para retirada de material particulado desde o início da operação comercial"

(BNDES, 2017h).

${ }^{11}$ A propriedade rural deve estar devidamente cadastrada no Cadastro Ambiental Rural (CAR), devido à Lei no 12.651/2012 que criou o novo Código Florestal. 
- Mineração:

- "Conformidade legal: o cumprimento das normas e regulamentações dos órgãos competentes. Exemplos:

- Regularidade junto ao Departamento Nacional de Produção Mineral (DNPM).

- Regularidade junto aos órgãos ambientais competentes.

- No caso de atividades de mineração de diamantes, regularidade junto ao Cadastro Nacional do Comércio de Diamantes (CNCD), vinculado ao Sistema de Certificação do Processo Kimberley; conforme Lei oㅜ 10.743/2003 e demais normativos aplicáveis".

- "Direitos humanos: atuação com respeito aos direitos humanos no ambiente de trabalho e no relacionamento com as partes impactadas pelo projeto, o que inclui a provisão de condições apropriadas de trabalho e de vida para os trabalhadores, a ausência de condenação relativa ao trabalho infantil ou forçado e à discriminação de raça ou de gênero, bem como 0 tratamento adequado a comunidades tradicionais e grupos locais. A atuação deve estar ancorada em política de direitos humanos da empresa".

- "Saúde e segurança do trabalhador e da comunidade:

- Existência de política e sistema de saúde e segurança do trabalho, com divulgação e capacitação para empregados e terceirizados.

- Realização de ações de educação, saúde e ações de promoção de segurança junto à comunidade local, inclusive em parceria com entes de governo".

- "Meio ambiente: existência de política e sistema de gestão ambiental, voltado para a melhoria contínua da prevenção e mitigação de impactos ambientais adversos, incluindo controle da qualidade do ar, gestão do uso e descarte de água, armazenamento e disposição de rejeitos, uso de substâncias perigosas, emissões de gases do efeito estufa e gestão da biodiversidade".

- "Impactos socioeconômicos na área de influência da mina:

- Gestão do relacionamento com as partes interessadas:

- Participação das partes impactadas pelo projeto, no âmbito do processo de licenciamento ambiental.

- Procedimentos apropriados para lidar com deslocamento populacional.

- Mecanismos para encaminhamento de demandas à empresa e práticas relativas à transparência e prestação de contas às partes interessadas.

- Desenvolvimento local: postura proativa e comprometimento com o desenvolvimento local, incluindo:

- A participação em discussões ampliadas, com o poder público e demais partes interessadas, relacionadas à mitigação dos impactos sociais do empreendimento. 
- A realização de investimentos sociais voltados para a comunidade".

- "Planejamento e encerramento das atividades: apresentação de plano de descomissionamento da mina e estabelecimento de alternativas de usos possíveis para a área reabilitada"

(BNDES, 2017g).

No caso de o projeto ser classificado como tendo um grande impacto, o banco pede para a empresa tomadora do crédito os Estudos de Impactos Ambientais (EIA/RIMA), obtidas junto aos órgãos ambientais. (BNDES, 2017e).

Desde 2008, o BNDES estabeleceu uma Cláusula Social em seus contratos de financiamentos, "que explicita o combate à discriminação de raça ou de gênero, ao trabalho infantil e ao trabalho escravo no Brasil". Com a inclusão dessa cláusula, "ao constatar desrespeito à legislação que trata do combate à discriminação de raça ou de gênero, ao trabalho infantil e ao trabalho escravo, o BNDES pode, de forma transparente e mais ágil, suspender ou exigir o vencimento antecipado do contrato de financiamento, impondo o pagamento imediato dos desembolsos efetuados" (BNDES, 2016g).

Com o estabelecimento da Política Nacional de Resíduos Sólidos, lei $\mathrm{n}^{0}$ $12.305 / 10$, foi imposto às instituições financeiras incentivar e financiar projetos que visem solucionar os problemas dos resíduos sólidos. Para incentivar esses tipos de projetos, o BNDES diminuiu a taxa de juros dos financiamentos (BNDES, 2018), além de apoiar, como por exemplo, o projeto "que busca desenvolver tecnologia nacional para tratamento e aproveitamento energético da Fração Orgânica dos Resíduos Sólidos Urbanos". Para esse apoio, o banco destinará $\mathrm{R} \$ 10,5$ milhões à Fundação de Desenvolvimento da Pesquisa (Fundep) (BNDES, 2013).

De acordo com a Lei de Acesso à Informação no 12.527/2011, todas as entidades e órgãos públicos devem divulgar suas informações para os cidadãos. Sendo assim, o BNDES, por ser uma empresa pública, pode receber solicitações de informações de qualquer cidadão através do Sistema Eletrônico do Serviço de Informação ao Cidadão ou em suas sedes diretamente (BNDES, 2016h).

Em relação à Lei anticorrupção estabelecida em 2013, o banco aprovou a criação da Política Corporativa Anticorrupção do Sistema BNDES (PCA), que é válida para "todos os Participantes do Sistema BNDES e às pessoas com as quais mantêm relacionamento" (BNDES, 2017a). Essa política possui como objetivos: 
- "Estimular um ambiente de comportamento ético, de envolvimento responsável e de práticas leais nas relações entre os Participantes do Sistema BNDES, Fornecedores, Clientes, Agentes Financeiros e Pessoas Relacionadas.

- Reforçar o compromisso do Sistema BNDES de cooperar proativamente com iniciativas nacionais e internacionais de prevenção e combate à corrupção, em todas as suas formas.

- Prevenir, detectar e punir desvios de conduta e práticas ilícitas cometidos por Participantes do Sistema BNDES, Fornecedores, Clientes, Agentes Financeiros e Pessoas Relacionadas que afetem de qualquer modo as entidades do Sistema BNDES.

- Orientar os Participantes do Sistema BNDES quanto à identificação de condutas e situações aplicáveis ao Sistema BNDES que possam configurar atos de corrupção e outros ilícitos assemelhados".

(BNDES, 2017a).

Com o estabelecimento da Política Nacional sobre Mudança do Clima, lei no 12.187/2009, as instituições financeiras foram obrigadas a fornecer linhas de crédito e financiamentos, para impulsionar as mudanças demandadas pela lei. Dessa Política, derivou-se a lei no 12.114/2009, que criou o Fundo Nacional sobre Mudança do Clima (FNMC). O BNDES passou a aplicar recursos reembolsáveis nesse fundo (BNDES, 2009). Esses recursos reembolsáveis são destinados ao Fundo Clima, que é um dos mecanismos do FNMC e é controlado pelo Ministério do Meio Ambiente. O Fundo Clima tem como objetivo "apoiar a implantação de empreendimentos, a aquisição de máquinas e equipamentos e o desenvolvimento tecnológico relacionados à redução de emissões de gases do efeito estufa e à adaptação às mudanças do clima e aos seus efeitos" (BNDES, 2018g). Através de financiamentos, o BNDES disponibiliza recursos desse fundo para projetos de Mobilidade Urbana, Cidades Sustentáveis e Mudança do Clima, Máquinas e Equipamentos Eficientes, Energias Renováveis, Resíduos Sólidos, Carvão Vegetal, Combate à Desertificação, Florestas Nativas, Gestão e Serviços de Carbono e Projetos Inovadores (BNDES, 2018g).

Com a promulgação da Lei das Estatais no 13.303/2016, o banco alterou seu Estatuto Social para atender às demandas estabelecidas pela lei. Algumas das mudanças foram: a "criação de novos órgãos colegiados estatutários (Assembleia Geral, Comitê de Elegibilidade e Comitê de Remuneração); critérios e requisitos para a nomeação de conselheiros e diretores, além de fixação de novos prazos de gestão; nova composição para os órgãos colegiados estatutários; estruturação de regras de compliance e controle interno; novas regras para destinação de resultados, distribuição de dividendos e capitalização 
do BNDES; vinculação do Banco ao Ministério do Planejamento, Desenvolvimento e Gestão; aprimoramento dos processos e estrutura de Ouvidoria e regras para resolução de conflitos" (BNDES, 2017j)

Para atender às exigências da Circular n 3.678/2013 do BACEN, o banco a cada ano divulga em seu site o Relatório de Gestão de Riscos, que "confere maior transparência às informações referentes à gestão de riscos, à apuração do montante dos ativos ponderados pelo risco (RWA) e à apuração do Patrimônio de Referência (PR) do BNDES". Com a divulgação desse relatório, o banco mostra o seu comprometimento em se manter financeiramente bem, para poder continuar a auxiliar no desenvolvimento sustentável (BNDES, 2018c).

Em relação ao Normativo SARB da FEBRABAN n 14 de 2014, não foi encontrada nenhuma informação se o BNDES segue ou não esse normativo.

\subsection{Mecanismos do Mercado}

Em 1995, o banco aderiu à iniciativa UNEP-FI, além de participar da criação do Protocolo Verde, juntamente com outras instituições financeiras e o governo federal e assiná-lo (BNDES, 2017d). Em 2008, o Banco reafirmou o seu compromisso com o Protocolo Verde após a sua atualização. As instituições financeiras que aderem ao Protocolo Verde "se comprometem a financiar o desenvolvimento com sustentabilidade, por meio de linhas de crédito e programas que promovam qualidade de vida da população e proteção ambiental" (BRASIL, 2008).

O Banco não assinou os Princípios do Equador ${ }^{12}$. Porém, ele utiliza uma classificação de risco bem parecida com a classificação apresentada nos Princípios. Também classifica suas operações, "levando em conta o setor, o tipo de atividade, a localização, magnitude e os atributos dos impactos ambientais do empreendimento". Após essa avaliação, o banco pode sugerir recomendações para o projeto.

12 Através de uma conversa informal, a área que trata das questões socioambientais do banco respondeu que o BNDES não assinou os Princípios do Equador considerando que o banco já utiliza os padrões de desempenho do IFC, que serviram de base para os Princípios do Equador. Além do que, nenhum banco de desenvolvimento assinou os Princípios, pelo fato de o volume de operações ser muito maior e eles não possuírem tanta liberdade de mudança, já que são uma empresa pública, o que poderia prejudicar o avanço dos princípios. 
Tabela 1 Classificação do Risco Ambiental

\begin{tabular}{|c|l|}
\hline $\begin{array}{c}\text { CATEGORIA } \\
\text { AMBIENTAL }\end{array}$ & \multicolumn{1}{|c|}{ RISCO DE IMPACTO ADVERSO } \\
\hline A & $\begin{array}{l}\text { Atividade intrinsecamente relacionada a riscos de impactos ambientais } \\
\text { significativos ou de alcance regional. O licenciamento requer estudos de impactos, } \\
\text { medidas preventivas e ações mitigadoras }\end{array}$ \\
\hline B & $\begin{array}{l}\text { Atividade envolve impactos ambientais mais leves ou locais e requer avaliação e } \\
\text { medidas específicas }\end{array}$ \\
\hline C & Atividade não apresenta, em princípio, risco ambiental significativo \\
\hline
\end{tabular}

Fonte: BNDES, 2018. BNDES, 2016c.

Em 2017, durante o "IV Seminário sobre a Localização dos ODS no Brasil: Parcerias para Integrar, Inovar e Incluir", promovido pelo BNDES e pelo Programa das Nações Unidas para o Desenvolvimento (PNUD), foi reafirmada a parceria entre as duas entidades, com o fim de auxiliar o Brasil a atingir os Objetivos de Desenvolvimento Sustentável (ODS) da ONU até 2030. O Banco afirma que sua missão está alinhada com os ODS (NAÇÕES UNIDAS NO BRASIL, 2017). Mesmo possuindo essa parceria com a PNUD, o banco não assinou o Pacto Global da ONU ${ }^{13}$. Também não foram encontradas informações sobre a Agenda 21 da ONU com relação ao BNDES.

Em 2016, o banco assinou o Pacto Empresarial pela integridade e contra a corrupção, que é uma das iniciativas do projeto Empresa Limpa, criado pelo Instituto Ethos, sendo baseado "na Convenção da ONU Brasil contra a Corrupção, na Carta de Princípios de Responsabilidade Social, no 10º princípio do Pacto Global e nas diretrizes da OCDE". Esse Pacto é "constituído de sete compromissos fundamentais, com procedimentos para a prevenção da corrupção e a difusão dos princípios entre a cadeia de valor" (BNDES, 2016e). Segundo o ex-presidente do BNDES, Luciano Coutinho, "a iniciativa é totalmente aderente aos valores do Banco e faz parte de um conjunto de ações que estão sendo implementadas, no âmbito da conformidade e da integridade, para aumentar a efetividade da contribuição do BNDES ao desenvolvimento do País e para favorecer a ética nos negócios" (BNDES, 2016e).

${ }^{13}$ Através de uma conversa informal, foi perguntado à área que trata das questões socioambientais do banco o motivo pelo qual o BNDES não assinou até hoje o Pacto Global da ONU. A área responsável relatou que, pelo fato de o banco ser um banco de desenvolvimento e possuir ações que correspondem aos princípios do Pacto, não achou necessário assiná-lo. Em sua cláusula social, o banco integra a maioria dos princípios contidos no Pacto. Além disso, o banco possui um comitê e uma área de gestão de riscos e de auditoria, políticas de gestão do risco, anticorrupção e compliance. 
O BNDES lançou em 2017, títulos verdes (Greens Bonds), para captar recursos, visando somente investir em projetos sustentáveis, nesse caso em projetos de energia eólica e solar. Foi a primeira vez que um banco brasileiro utilizou esse recurso no mercado internacional. Esses títulos ajudam "a consolidar a presença internacional do BNDES e proporcionam uma série de benefícios, entre os quais podem-se (sic) citar: reforçam a prioridade dada pelo Banco ao tema da sustentabilidade socioambiental; promovem a difusão das melhores práticas de gestão socioambiental; incentivam o acesso de outros emissores brasileiros ao mercado de green bonds; e constroem um novo ponto de referência em sua estrutura a termo de taxa de juros internacionais" (BNDES, 2018h).

O banco expõe em seu site que procura estar "alinhado a documentos externos de referência" no que diz respeito à responsabilidade socioambiental, como por exemplo, a ISO 26000, que inclusive serviu de base para sua Política de Responsabilidade Social e Ambiental (BNDES, 2018b).

O BNDES, para avaliar o risco de um empreendimento, leva em consideração as "visões e práticas socioambientais" da empresa, que pede o financiamento (BNDES, 2014b), além dos "níveis de gestão e governança", pois esses elementos "são fatores determinantes nos impactos efetivamente gerados pelos empreendimentos por ela desenvolvidos". Alguns exemplos de mecanismos que o BNDES observa e que as empresas podem adotar para diminuir seus impactos e melhorar sua classificação de risco são: Sistema de Gestão Ambiental (SGA); possuir certificados da série ISO 14.000, ISO 9.000, OHSAS 18.000, SA8000 e NBR 16001; ter uma Política Socioambiental regularmente definida; divulgar anualmente seu relatório de sustentabilidade e ter uma área específica para cuidar das questões socioambientais (BNDES, 2014b).

Em relação ao Carbon Disclosure Project, não foram encontradas informações sobre esse projeto no que diz respeito ao BNDES. Porém, o banco possui diversos projetos que buscam incentivar a diminuição da emissão do carbono, além de, recentemente, citar em seu Plano Plurianual 2018-2020 da PRSA a inclusão da questão da mudança climática na estratégia do banco. Entre eles:

- Programa BNDES Desenvolvimento Limpo: criado em 2007, o projeto "prevê a criação de fundos mútuos fechados de investimento para apoiar projetos capazes de gerar RCEs (documentos conhecidos como Redução Certificada de 
Emissões), no âmbito do Mecanismo de Desenvolvimento Limpo (MDL), do Protocolo de Kyoto. Os RCEs são créditos de carbono negociados no mercado internacional e estão vinculados a projetos que adotem tecnologias limpas em detrimento de tecnologias poluentes". Para esse programa, o Banco destinou $\mathrm{R} \$ 200$ milhões e ficou vigente até 2009 (BNDES, 2007).

- Fundo do Índice Carbono Eficiente: o BNDES em parceria com a BM\&FBOVESPA lançou em 2010, "um novo fundo de índice formado por ações de empresas que compõem o Índice de Carbono Eficiente (ICO2)" (BNDES, 2011a). O principal objetivo desse índice é "incentivar as empresas emissoras das ações mais negociadas a aferir, divulgar e monitorar suas emissões de GEE, preparando-se, dessa forma, para atuar em uma economia chamada de "baixo carbono". Além disso, visam prover o mercado com um indicador cuja performance será resultante de um portfólio balizado por fatores que incorporam, inclusive, as questões relacionadas às mudanças climáticas" (BM\&FBOVESPA, 2016a).

- Através do Fundo Clima, o BNDES possui um Subprograma, denominado Gestão e Serviços de Carbono, que visa "apoiar projetos que melhorem a gestão de emissões de carbono ou que efetivamente reduzam as emissões de gases de efeito estufa" (BNDES, 2018f).

Sobre o Índice de Sustentabilidade Dow Jones e o Índice de Sustentabilidade Empresarial da Bolsa de Valores de São Paulo, não foram encontradas informações se o BNDES utiliza esses índices ou não. Porém, como mencionado acima, o banco fez uma parceria com o Índice de Sustentabilidade Empresarial da Bolsa de Valores.

Com relação aos indicadores Ethos de Responsabilidade e os Indicadores Setoriais Ethos-Febraban de Responsabilidade Social Empresarial, o banco não utiliza esses indicadores.

No que diz respeito à GRI, o banco utiliza essa ferramenta internamente e disponibiliza em seus relatórios anuais as informações relacionadas a essa ferramenta. Inclusive, em seu último relatório divulgado em 2016, o banco passou a utilizar os 54 indicadores presentes na GRI Standards (BNDES, 
2016d). Porém, não foram achadas informações se o banco exige dos tomadores de crédito a utilização desse mecanismo.

O BNDES, em 2017, assinou um memorando de entendimento com duração de dois anos com a Corporação Financeira Internacional (IFC), visando fortalecer a "dimensão socioambiental nos projetos financiados". Essa parceria vai auxiliar o BNDES a alinhar suas políticas socioambientais com os padrões de desempenho utilizados na IFC. Nesse memorando, está incluso "o mapeamento de potenciais áreas de aprimoramento de políticas e procedimentos socioambientais do BNDES e a troca de conhecimento entre bancos de desenvolvimento regionais do Brasil e bancos de desenvolvimento de mercados emergentes". Com a celebração desse acordo, houve benefícios para ambos. "Para o Banco, os benefícios incluem a consolidação do seu papel como protagonista na promoção do desenvolvimento socioambiental sustentável, o maior alinhamento com expectativas da sociedade quanto à atuação socioambiental da instituição e o constante aprimoramento em relação aos requisitos socioambientais exigidos em processos de captação de recursos", enquanto que "para a IFC, essa parceria contribui para o cumprimento de sua missão de promover práticas mais sólidas de avaliação socioambiental em instituições de desenvolvimento" (BNDES, 2017b). 


\section{Conclusões}

A partir das mudanças que o mundo vem sofrendo devido aos problemas ambientais e sociais que, com o passar dos anos, foram se agravando, a questão da sustentabilidade e da responsabilidade socioambiental está ganhando força e cada vez mais se discute a importância, tanto das pessoas quanto das empresas em especial, repensarem o tipo de desenvolvimento que só leva em conta a parte econômica e começarem a adotar um desenvolvimento mais sustentável.

Neste sentido, com os novos desafios impostos por esse desenvolvimento, uma sociedade mais consciente e um meio ambiente à beira de um colapso que necessita de atitudes mais responsáveis, as organizações estão percebendo que é necessário haver mudanças de atitudes. Isso tudo tem levado tais organizações a repensar e rever sua responsabilidade socioambiental, tanto internamente quanto perante a sociedade. Portanto, podemos concluir que as instituições financeiras possuem um papel importante nesse desenvolvimento, pois, mesmo não exercendo uma atividade diretamente poluidora, elas impactam a sociedade e o meio ambiente através de seus financiamentos e empréstimos a empresas, governos e sociedade.

Assim sendo, acreditamos que conseguimos mostrar a importância de as instituições financeiras adotarem práticas mais sustentáveis e influenciarem o mercado a adotá-las igualmente, através de suas políticas de financiamento e crédito.

Para tanto, realizamos um levantamento bibliográfico que definiu os principais termos relacionados ao tema, que são: responsabilidade socioambiental e sustentabilidade. Ademais, foram apresentadas e analisadas as legislações e normas vigentes e os principais mecanismos do mercado relacionados ao meio ambiente e ao social, materializada e demonstrada a importância do tema a partir do exemplo do BNDES, onde analisamos a importância indutora e multiplicadora do Banco em relação às demais empresas, a partir das exigências e sugestões dos mecanismos e políticas adotados por esta instituição nacional de desenvolvimento econômico e social. 
A partir do método adotado e da coleta de dados, foi observado que de todas as leis, normas, circulares e normativos apresentados no capítulo dois, somente em relação ao Normativo SARB da FEBRABAN n 14/2014 não foram encontradas informações se o BNDES o segue ou não. Porém, pelo fato de esse normativo seguir a resolução no $4.327 / 2014$ do Banco Central e especificá-lo com mais clareza, pode-se inferir que o banco indiretamente também segue essa norma.

Já em relação aos 17 mecanismos do mercado apresentados no capítulo dois, o banco utiliza dez deles. Os que o banco não utiliza são: Os indicadores Ethos de Responsabilidade e os Indicadores Setoriais Ethos-Febraban de Responsabilidade Social Empresarial, o Índice de Sustentabilidade Dow Jones, o Índice de Sustentabilidade Empresarial da Bolsa de Valores de São Paulo e Carbon Disclosure Project, os Princípios do Equador, o Pacto Global e Agenda 21. Porém, mesmo o banco não adotando os mecanismos acima, possui inúmeras outras ações, como foi observado no capitulo quatro.

Podemos também inferir que inúmeros mecanismos que auxiliam no alcance do desenvolvimento sustentável estão disponíveis. Fica a cargo, assim, das organizações e instituições financeiras decidirem adotá-los e se comprometerem verdadeiramente, engajando-se a esse movimento e assumindo um papel que o momento exige, tendo um olhar para um futuro possível e em equilíbrio, protagonizando, com os instrumentos existentes, os desvios de rota que permitirão que as atividades sustentáveis deixem de ser alternativas ou excepcionais, para ser o padrão.

Com os dados obtidos, pode-se observar que o BNDES possui uma Política de Responsabilidade Social e Ambiental (PRSA) consolidada e que norteia todas as ações do banco. Além disso, instaurou o Comitê de Sustentabilidade Socioambiental (CSS) para coordenar e supervisionar internamente tudo o que for relacionado à questão socioambiental. Com a criação desse comitê, foi implementado o Plano plurianual de ações, com o objetivo de auxiliar na implementação da PRSA, sendo atualizado a cada três anos.

Podemos verificar ainda que o BNDES por ser uma instituição pública, divulga a maioria das suas informações relacionadas à questão da responsabilidade socioambiental e desenvolvimento sustentável em seu site, que pode ser acessado por todos.

Com a análise dos mecanismos de mercado e da legislação adotados pelo BNDES e os apresentados no capítulo dois, podemos concluir que o banco 
possui inúmeras ações que mostram que está realmente preocupado com a questão do desenvolvimento sustentável e da sua responsabilidade socioambiental perante a sociedade e o desenvolvimento do país. O banco inclui também em sua missão esta questão: "viabilizar soluções financeiras que adicionem investimentos para o desenvolvimento sustentável da nação brasileira". Também corrobora para nossas conclusões que, mais recentemente, o Banco passou a adotar em sua estratégia os Objetivos de Desenvolvimento Sustentável da ONU (ODS) e a mudança climática, com o intuito de auxiliar o país a atingir os objetivos estabelecidos pela Agenda 2030, que chegou para substituir a Agenda 21 da ONU.

Uma sugestão para o BNDES seria que o banco desenvolvesse uma ferramenta específica que o auxiliasse na avaliação da efetividade dos mecanismos adotados em condicionar as empresas tomadoras de crédito a uma maior responsabilidade socioambiental e verificar se essas empresas que receberam financiamentos estão, com efeito, contribuindo para o desenvolvimento sustentável, trazendo benefícios positivos para a sociedade e o meio ambiente.

À luz do exposto, pode-se concluir que, se outras instituições financeiras realmente se engajarem na adoção desses mecanismos e instrumentos de sustentabilidade nessa luta, como observado no BNDES, podem influenciar e até condicionar o mercado na direção de um desenvolvimento que não leve em consideração só a parte econômica, mas a social e a ambiental também.

Ao adotar os mecanismos e legislações existentes, as instituições financeiras dão o primeiro passo rumo ao desenvolvimento sustentável. Contudo, essa atitude é só o começo e deve ser aprimorada, pois a questão da sustentabilidade não é uma discussão momentânea, porém contínua, devendo ser aprimorada com a participação de todas as esferas sociais.

Entretanto, ao adotar esses mecanismos e legislações, as instituições devem praticá-los com rigor, fiscalizando e controlando os empreendimentos e projetos financiados por elas do inicio ao fim, colocando estes mecanismos no seu processo de planejamento, gestão e controle. Ao constatarem que os tomadores do crédito não estão seguindo os requisitos exigidos no contrato de financiamento, devem adotar critérios rigorosos, até mesmo punindo com o cancelamento do crédito ou a proibição de novas contratações, influenciando e condicionando dessa forma as empresas tomadoras do crédito a adotar práticas mais sustentáveis. 
Este trabalho, assim como os resultados obtidos, pode ter uma futura contribuição no âmbito acadêmico e empresarial, pelo fato de a humanidade estar se conscientizando sobre a importância de um desenvolvimento mais sustentável e a necessidade de as empresas se adaptarem aos novos desafios estabelecidos por este desenvolvimento.

Em relação às instituições financeiras, os resultados do trabalho podem servir também de guia para que analisem se seguem os mecanismos obrigatórios e de mercado, e assim contribuam para uma economia mais sustentável.

\subsection{Sugestões de trabalhos futuros}

Estudos futuros poderiam continuar a discussão da responsabilidade socioambiental das empresas e, especialmente, das instituições financeiras, tema tratado neste trabalho. Sugerem-se ainda novos estudos sobre a importância da responsabilidade socioambiental no âmbito das instituições financeiras, por ser ainda um tema pouco estudado, bem como a utilização de mais de uma instituição financeira para fins de comparação. Pode-se ainda tentar obter um panorama do setor, objetivando analisar mais a fundo o tema em trabalhos e estudos de pós-graduação em administração. 


\section{Referências Bibliográficas}

ALYRIO, Rovigati Danilo. Métodos e Técnicas de Pesquisa em Administração. Rio de Janeiro: Fundação Cecierj, 2009. Disponível em: $<$ https://canalcederj.cecierj.edu.br/recurso/6448>. Rovigati Danilo Alyrio.pdf>. Acesso em: 07 maio 2018.

ASSOCIAÇÃO DOS PRINCÍPIOS DO EQUADOR. Membros da Associação e Relatórios. 2018b. Disponível em: <http://equatorprinciples.com/members-reporting/>. Acesso em: 28 abr. 2018.

ASSOCIAÇÃO DOS PRINCÍPIOS DO EQUADOR. Os Princípios do Equador. 2018a. Disponível em: <http://equator-principles.com/about/>. Acesso em: 27 abr. 2018.

BM\&FBOVESPA. (Brasil). Índice Carbono Eficiente - ICO2. 2016a. Disponível em: $\quad$ <http://www.bmfbovespa.com.br/pt_br/produtos/indices/indices-desustentabilidade/indice-carbono-eficiente-ico2.htm>. Acesso em: 21 maio 2018a.

BM\&FBOVESPA. Sobre a BM\&FBOVESPA. 2016b. Disponível em: $<$ http://www.bmfbovespa.com.br/pt_br/institucional/sobre-a-bm-fbovespa/quemsomos/>. Acesso em: 26 abr. 2018b.

BNDES. BANCO NACIONAL DE DESENVOLVIMENTO ECONÔMICO E SOCIAL - BNDES. Nossa história. 2016b. Disponível em: <https://www.bndes.gov.br/wps/portal/site/home/quem-somos/nossa-historia>. Acesso em: 11 maio 2018.

BNDES. BANCO NACIONAL DE DESENVOLVIMENTO ECONÔMICO E SOCIAL - BNDES. . BNDES lançará Fundo do Índice Carbono Eficiente na BM\&F BOVESPA. 2011a. Disponível em: <https://www.bndes.gov.br/wps/portal/site/home/imprensa/noticias/conteudo/201 10118_ico2>. Acesso em: 21 maio 2018.

BNDES. BANCO NACIONAL DE DESENVOLVIMENTO ECONÔMICO E SOCIAL - BNDES. BNDES cria programa de $\mathbf{R} \mathbf{2} 200$ milhões para estimular negociação de créditos de carbono. 2007. Disponível em: $<$ https://www.bndes.gov.br/wps/portal/site/home/imprensa/noticias/conteudo/200 70605_not126_07>. Acesso em: 21 maio 2018.

BNDES. BANCO NACIONAL DE DESENVOLVIMENTO ECONÔMICO E SOCIAL - BNDES. . BNDES adere a novo Protocolo Verde e reitera seu compromisso com preservação ambiental. 2008. Disponível em: $<$ https://www.bndes.gov.br/wps/portal/site/home/imprensa/noticias/conteudo/200 80731_not118_08>. Acesso em: 17 maio 2018. 
BNDES. BANCO NACIONAL DE DESENVOLVIMENTO ECONÔMICO E SOCIAL - BNDES. BNDES apoia desenvolvimento de tecnologia nacional para tratamento de resíduos sólidos. 2013. Disponível em: <https://www.bndes.gov.br/wps/portal/site/home/imprensa/noticias/conteudo/201 31121_fundep>. Acesso em: 19 maio 2018.

BNDES. BANCO NACIONAL DE DESENVOLVIMENTO ECONÔMICO E SOCIAL - BNDES. Fundo Nacional sobre Mudança do Clima - FNMC. 2009. Disponível em: $<$ https://www.bndes.gov.br/wps/portal/site/home/transparencia/fontes-derecursos/fundos-governamentais/fundo-nacional-sobre-mudanca-do-climafnmc>. Acesso em: 15 maio 2018.

BNDES. BANCO NACIONAL DE DESENVOLVIMENTO ECONÔMICO E SOCIAL - BNDES. Quem somos. 2017. Disponível em: <https://www.bndes.gov.br/wps/portal/site/home/quem-somos>. Acesso em: 11 maio 2018.

BNDES. BANCO NACIONAL DE DESENVOLVIMENTO ECONÔMICO E SOCIAL - BNDES. Política Corporativa Anticorrupção do Sistema BNDES PCA. 2017a. Disponível em: $<$ https://www.bndes.gov.br/wps/portal/site/home/quem-somos/etica-ecompliance/!ut/p/z0/fY7LCslwFES_pktJxPey4AtbEFxIzSZck1CvtrlpkpZvtGVK5dnZpgZJljFhIUBa4hIFprEN7GU5abYHednXh4ufMrzRbHPr9tituYrdmLifyA 14LPrRM6ElhvNGFl1t9oEiTZEjL36LmX8Qa3JuKUJJnfMulmolEE0tUcNOpnNLz hq8BORirwjnx4PIMEmibzvnQKSmmTAEE0LMk0y9xK3Nw5Imco!/>. Acesso em: 15 maio 2018.

BNDES. BANCO NACIONAL DE DESENVOLVIMENTO ECONÔMICO E SOCIAL - BNDES. BNDES assina parceria com IFC para fortalecer dimensão socioambiental nos projetos financiados. 2017b. Disponível em: $<$ https://www.bndes.gov.br/wps/portal/site/home/imprensa/noticias/conteudo/bnd es-assina-parceria-com-ifc-para-fortalecer-dimens-o-socioambiental-nosprojetos-financiados>. Acesso em: 21 maio 2018.

BNDES. BANCO NACIONAL DE DESENVOLVIMENTO ECONÔMICO E SOCIAL - BNDES. Histórico da atuação socioambiental. 2017d. Disponível em: $\quad<$ https://www.bndes.gov.br/wps/portal/site/home/quemsomos/responsabilidade-social-e-ambiental/o-que-fazemos/historico-atuacaosocioambiental/historico-atuacaosocioambiental/!ut/p/z1/zZPLcpswFlafpQuWsgSIW3fEIXYCjtOmqQ0bjwABakHCI Ju0T1-

ZZuG4E3sy2VQ7zpz_Mh8STOAaJpzsWUkkE5zU6jtO7E3khcEcL1GEHq9M5F8 7t1Y081BoYrgaF9Abx0cwOdYvr5Gj9FP7_sE29ekNht9hApOMy1ZWME55TvsN4 $71 \mathrm{kcpeNDTRUiYZqaLujDehFI3oNdbRvBe9JymqWk5yqecZIDUiTMsrIQSSAEoC}$ C_KajomK9FB3LBCByRzliRok4ElzaONRsM5bDmKS2Y6cpBImBDYAdagLXS23 gY̌gdjrOeeYZAXLGe4JeeprQ55xw6zh_sb5FtfrtAswHoYGqcLy1szQP58Glk4CP WZZ74snAmJVUnn7ZIWXO0ZHeATF12jCDy-k8H8Usld_mDCBXv9g_Z3rwn_xPV62A_ttvEV1dYcEmfJVz_z3dY9TW6xXRRKgxEVoDxQsD1RZniUNYi_Wvg89 R0IUFHC'9rRbrLr1LiSsu0_a0hDwzBMRgSTUuwnaacmrSrfim6s2DNJ34ODglftT8 Mr0Svkp5mwbZ4a1_wFfn51h29FVTabRWBa9T4qFtKK_U9_ALR4AsQ!/dz/d5/L2 dBISEvZOFBIS9nQSEh/>. Acesso em: 17 maio 2018. 
BNDES. BANCO NACIONAL DE DESENVOLVIMENTO ECONÔMICO E SOCIAL - BNDES. Análise socioambiental. 2017e. Disponível em: <https://www.bndes.gov.br/wps/portal/site/home/quem-somos/responsabilidadesocial-e-ambiental/o-que-fazemos/relacionamento-clientes/analise-

socioambiental>. Acesso em: 18 maio 2018.

BNDES. BANCO NACIONAL DE DESENVOLVIMENTO ECONÔMICO E SOCIAL - BNDES. Critérios ambientais para apoio ao setor de açúcar e álcool. 2017f. Disponível em: <https://www.bndes.gov.br/wps/portal/site/home/quem-somos/responsabilidadesocial-e-ambiental/o-que-nos-orienta/politicas/politica-socioambiental/criteriosambientais-setor-acucar-

alcool/lut/p/z1/1 VRRe5owFP0tfeAxJhgQ3Rtaip3Ydu2syotfwADZIMEkartfv8jadZ9 -svXr03gh3Nxzz7nnJsAYLmDMyY7IRDPBSWm-

I3FvFQ0mwdi5RRF6GGLkX3rXbhQOUDjz4LxJQGceH8H4PP7RdeAjjGGccl3rAi 4TvqZqxbjSTG_TRoGFCIFRC222tAJKVEJZSFJVC65lwkq2Jmtq4ikjJSBVwijXB5 AABgC4UEDIJmahWpRMs5Sot2UDFH_AUsk0lczAXoNMAUW1kICk25SYV5kK UR5E1ylbw-XAdpwuTQiwcYaBY7s19F1ig3W_1-

Ass6mHyYtJLS7G7R7OD3znK0wc3J4QRvZxwu018kzCqHdz18P26Mo5Tgjvbq6 Q734ZojBw7Mmke1LhGgflH48i1wkmdjh41dDSx9L44J0VaffgfMfoHs64kJU5fA_vt Hn8Vwbvgwzt5cfdD5b_3DpEc07MdWTfNpvYN3dGcE2fNFz8P5fGqO_K6WiaḠ1 OILgDjmYCL3xRvyyMKuPhnCuNgXork15_L5wnuGzJJMyqp7GylCRdā1qThSy03-87jXmdXOw6iTSRuulTNm0pQ_kelmpIRn5QV8wJWIGU5I9AdLykEfNBjHTYoqeNHwqvhDKDPtYM6yrWdXHzD7fXDf33_NirxaTQPsIrto2H_GZe5fXPwEmN7EKQ!!/dz/d5/L2dBISEvZ0FBIS9nQ SEh/>. Acesso em: 19 maio 2018.

BNDES. BANCO NACIONAL DE DESENVOLVIMENTO ECONÔMICO E SOCIAL - BNDES. Política Socioambiental para o Setor de Mineração. 2017g. Disponível em: <https://www.bndes.gov.br/wps/portal/site/home/quem-somos/responsabilidadesocial-e-ambiental/o-que-nos-orienta/politicas/politica-socioambiental/politicasetorial-mineracao/!ut/p/z1/zZRNc9owEIZ_Sw8-Csn4A-

jNIQ6kmHwnBF8Y2ZaxWlsykoC0v76LQyYdUpzpZDJTX2zt7rt69VgSjvEjjgXd8C U1XApawnge-4toMAnH7iWJyO2JQ4LT3rkXjQakb7t41hSQI09AcHxc_C5AHHOE6FqU2B54nImF5woQ0367RxYJFCVswiQilO2SeLKKZrKTRNeMkzmjGkZ cppiWiVcCbMTiLRas2QkBpJ1cQsUsuSG55S_frZCOUfstcEMyCEnhUXTNGUyp 3LOuUZnjt9O03T3EfMpjZyEz9HSe4NUJYlvtfzHebl3T2VFmxxO7TZbr7jHSau014 wiuzDgstT0oOCoX9x5Tv28Mw9LBhdXZyRwLs-

laPQtSeT7psO505IgvEw8txwYo8GLx5a1jEHDr3jHDw823C2xfdCqgp22-

0_Yh6_N8PY_eAM77S3P7e986ntB-SD7b-

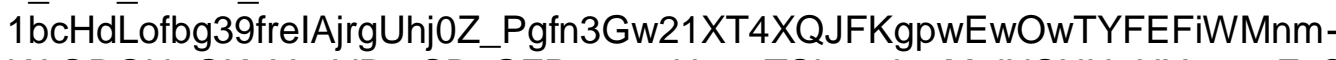
KAOROH3QKpYzxVRnrSBcGFPrrxaxyHa77TSL7yzlppMoiNSNU9UY09ywFxCw sgqcV1 IfR8HewsjpL7bXILRBW0FeorTc1TFIUKDNNTug8jfzhdTwsw4947q6r_rO T_TjJrzpb-_yYlktpqHj7V_IJsqnxpt_-

Q2LQNem/dz/d5/L2dBISEvZOFBIS9nQSEh/>. Acesso em: 19 maio 2018.

BNDES. BANCO NACIONAL DE DESENVOLVIMENTO ECONÔMICO E SOCIAL - BNDES. . Critérios socioambientais para apoio ao segmento de geração elétrica. 2017h. Disponível em: <https://www.bndes.gov.br/wps/portal/site/home/quem-somos/responsabilidadesocial-e-ambiental/o-que-nos-orienta/politicas/politica-socioambiental/criteriossocioambientais-geracao-eletrica/!ut/p/z1/1VRNd9owEPwtOfgoJHB6c0Qx6SYJE1KAF94si3bam3JSAKa_voKN21aeLiPI1N9klc7O7OzkmAMlzBme EcLrChnuNL_q7i_jobTYOLcowg9jWzkXw9u3SgconAgls2AZ35fATj8_hn14HPMIZxyISjSrhKWEbkmjKpqNqmrQIDlbwmBtpsSQ0kr7k0k 
CCy4UzihFY0wxnR8ZTiCuA6oYSpA4gDDQCMS8BFGzNQwyuqalrl27IF8j9gqaC KCKphf-1QCQoiclo5IBVRQkMPspuUZnDloowgy-

yDPM8s4JiWCZLUyUHiJWiYpKntOcNXmzp8jLtdXBz4zleYOnZ3QhiZxwn312igE 8b9u4e-

bY5vnOOE8OHuBvnupxEKA8ecTq2TCrd2gPzJOHKdYGqGw18aOvpYaR8GZ0 WafbjYUbKHc8ZFrY_f04U2T_7JMHgnQ3f5ifXO8h87h6jPib6Q9MtmE_v61nCmy DcFI_TtdH6LTEbzwptC1YloCzzncPmb5G15RAKXF5BoF4uKJz_fL58ItqfpBMmJI KK3FTpcKtXIDwYy0H6_77UG9gq-6yVCR5q2V9G2JjXpJWaSUztz_J28YircjqfWxyk1SGP6A2sJ0YIOWn5VHzJpR74sWbY1PPas1_A18fg0dt_zsuiXs8C26120ch7 savCv7r6ATRE3HY!/dz/d5/L2dBISEvZOFBIS9nQSEh/>. Acesso em: 19 maio 2018.

BNDES. BANCO NACIONAL DE DESENVOLVIMENTO ECONÔMICO E SOCIAL - BNDES. . BNDES muda Estatuto Social para se adaptar à nova

Lei das Estatais. 2017j. Disponível em: $<$ https://www.bndes.gov.br/wps/portal/site/home/imprensa/noticias/conteudo/bnd es-muda-estatuto-social-para-se-adaptar-nova-lei-das-estatais>. Acesso em: 20 maio 2018.

BNDES. BANCO NACIONAL DE DESENVOLVIMENTO ECONÔMICO E SOCIAL - BNDES. Avançar Cidades - Saneamento. 2018. Disponível em: $<$ https://www.bndes.gov.br/wps/portal/site/home/financiamento/produto/avancarsaneamento>. Acesso em: 19 maio 2018.

BNDES. BANCO NACIONAL DE DESENVOLVIMENTO ECONÔMICO E SOCIAL - BNDES. Plano de Implementação da Política de Responsabilidade Social e Ambiental. 2018a. Disponível em: <https://www.bndes.gov.br/wps/portal/site/home/quem-somos/responsabilidadesocial-e-ambiental/o-que-nos-orienta/politicas/plano-implementacaoprsa/lut/p/z1/vVRNc9owEP0tPfgoJPwp92YcYhLIVykFfMnlsgxqbctYApL-sqUmXRIMEmZ1hdZq9Xbfat9C2M4g3FJNnxBFBclyfV-

HruPI3_YH9h3alTGPQsFF96VM4p8hEMPTncO6MgXIBgfvx9NPPgNxjCmparUE s6TMmXykZdScbWmuwwMtBQFM1ApANenTwaqmaxEKUnCc56SIAEpKCc5IEX CWamaKwKs1gyUQgJR72wGqkTOFadE6t-

cNGhFlbOiOaREgKqWpMmkojyF88xPEe06FDDbdYCNMwQwQxR4mclokpHU8f 098xZq8Xsq1-IQtxd22uT7J0J0f3uJAuehh6K-3R0OzUOHuyurj4JBOHLs_rAbdbeoe31DhAukKeTDN3be9fqhpc2nGsW3tEqdF043XC2hZNS1IXup_FLkamNPc SIDRKCfWAnCQbEtTzAqGUmrulh27HgAJ2K4J0ZoR1-

YJ4Jf31KAFph_PtqFQdaBqJU7EnBWYsOdGMXuuMLIf9WCa9MTQpmfRPeLD QzopZaaJmAs 9 dmssiF8nvsRCUiYX1jZplrGZ1Z11r81KpSn42kIG2221nR6OzEJtOUmtL1WhP1Lu 8JFfsl5TYC6m3gi-F1GU7jNn-tnjc0pzvmgAn4L1_Cm-aZ8JfnxpQH-zM_zGh37Uo-5VMSmw9czBjy-Dn71bEIUJ3n7NiilW-NnKNoVrxe9XXz6BZb_kvw!/dz/d5/L2dBISEvZ0FBIS9nQSEh/>. Acesso em: 20 maio 2018.

BNDES. BANCO NACIONAL DE DESENVOLVIMENTO ECONÔMICO E SOCIAL - BNDES. 0 que nos orienta. 2018b. Disponível em: $<$ https://www.bndes.gov.br/wps/portal/site/home/quem-somos/responsabilidadesocial-e-ambiental/o-que-nos-orienta/o-que-nos-

orienta/!ut/p/z1/vVPLctowFP2WLrwUEpZfdOcQx6RASJtSsDeMZISt1 paMJHD69 xVuZprmQSeTmWqnM_fe89AVzOEa5olceUkMI4LU9p7IwWY2miYTb4Fm6O4C o_gyvPZn6QilyxCu-gL0yokRzB_3Ly5RaPvHwc1tglfjKw9-

gznMC2FaU8GMii3TGy604eZQ9AocVMmGOWh_YA3QspHaQYrpVgpNKK_5lm yZxQtOakAaypkwpyYJbAMQUgOpeuwF6MTcFnwLs8KLQsSIByiJRsCjNAlkwCF 
gBXZp4laR5-MHp2eiyM8HsTrxPZ6Q3t5codj_flHSxBtOp-

7TgsU1TIA8Gc98L5kO0xF-

KDhDklmR4asihwFcHTnr4FJI1djnvXtjBpN_MoTvZDg_fuK-c_ynvxN-

oh24fn3_T6P7VZKYdi9gev_vJZWgqvm43/pnRFTAS52Eq6f11kvZS3p718aC4oj

26HYjimmBgdl4cqYVn90kIO6rhv0NgalPA6oskhrJbdS9bo0N-wtltgfUy-

RV1Lb2J5ywrZZNhH-CX58ibqvu6psNvME-

_VxtpsbP4s_AIDFjaW/dz/d5/L2dBISEvZOFBIS9nQSEh/>. Acesso em: 20 maio 2018.

BNDES. BANCO NACIONAL DE DESENVOLVIMENTO ECONÔMICO E SOCIAL - BNDES. Relatório de Gestão de Riscos. 2018c. Disponível em: $<$ https://www.bndes.gov.br/wps/portal/site/home/relacoes-com-

investidores/relatorios-de-gestao-de-riscos/relatorio-gestao-

riscos/lut/p/z1/vVNNU8IwEP0tHnoMSZsWireKDF9FxlGE5uL0I22jNME0UvXXu4

AHHQXHcTSXTHbfvrcv2WCGI5jJeCOK2Agl4xWcl9a-

DbuT_tCdkXBwc3ZOgnB0FQ7mhM5GHI7sAOTACghm7-

v9HoSCc6cT0vDamfRsfIMZZqk0a1PiKJEZr2-Frl0wj-

muA4uUqulW0XwVp7FCqaqQkBsOkExpXu8zRmmhUAFRgGhRp-

pwYiu4TkWGI6-

T27SbecjJU47czM9QEns28jIxUxp7bZ_SN4NHboAd97_Y6r1nml1onwTDXui5_Y k96NI3wBGOCHroHOwhcPFil3iD51 LpCh7t6ocWh98qeL9UOE5 af8tvfNL-

vHHB_w8AvBLxN3DAwtglJU0_Mng5f_MMig7etqbFmAoNiXQ5QovD6HBSLFSyf 5fBzKhPtRpnnPNdetRQ7g0Zl2fWsQiTdO0CqWKFW9Bn61EW-SrqILVYPYTGKreeXTZ3SfT_vUjcabl7MLtN1CvkAseW6Ck5NXSXUFMA!!/dz/d5/L2dBISEvZ0FBI S9nQSEh/>. Acesso em: 20 maio 2018.

BNDES. BANCO NACIONAL DE DESENVOLVIMENTO ECONÔMICO E SOCIAL - BNDES. Políticas. 2018d. Disponível em: $<$ https://www.bndes.gov.br/wps/portal/site/home/quem-somos/governancacontrole/planejamento-corporativo/o-bndes>. Acesso em: 11 maio 2018.

BNDES. BANCO NACIONAL DE DESENVOLVIMENTO ECONÔMICO E SOCIAL - BNDES. Missão, Visão e Valores. 2018e. Disponível em: <https://www.bndes.gov.br/wps/portal/site/home/quem-somos/governancacontrole/planejamento-corporativo/missao,-visao-e-

valores/!ut/p/z1/vVPNUtswEH4WDr5VkWLZjunNMCYhcaAdBhLrwshGtkVjyZEU p_D03aQcWiBhOsxUF412dr-f3RVmelmZ4r2suZNa8RW8cxbdZ6ezdBJck-

w6uCMkCcNxNqXEJzchXuwTyIGTEMz-rB9_u7qA-

u9nZJwGw9nMx3eYYVYq17kG54V6EPZeKüuk25R7BR5pdCs8st6IFIndauuRWv fCKK5KjkqtnNErSBDWGe5ELXdB0214yJ57pJXWcv0F9RluJFDPV9olu6PtSvmA 8yogNloDgiithiioloq4H4UoHA1Hgtl4FhF9sXmkD-x4FxY7vr8QLmIKksl5FgbpbDgpS8JRzBy0DA6qMEP8KKXYotvITYtjO7mHy1OPmQIP8IwHP6SfBJ--

qrDb2YEyywf12uWwMbB3oifDi_58oBv2_m5_MabHHXIKkqjZeHssFOvdLF70YqILGUGdEJYwwg42BcONcZ796xCPb7XawdzIAoYPCQKQD1SDJ7fxY6cRbVhNtpCU17D4a69bWP6hH5U85QG-

bR_PrtCrHliiz5IYJCcnvwBfKVvL/dz/d5/L2dBISEvZOFBIS9nQSEh/>. Acesso em: 15 maio 2018.

BNDES. BANCO NACIONAL DE DESENVOLVIMENTO ECONÔMICO E SOCIAL - BNDES. 2018f. Fundo Clima - Subprograma Gestão e Serviços de Carbono. Disponível em: <https://www.bndes.gov.br/wps/portal/site/home/financiamento/produto/fundoclima-gestao-servicos-carbono>. Acesso em: 21 maio 2018. 
BNDES. BANCO NACIONAL DE DESENVOLVIMENTO ECONÔMICO E SOCIAL - BNDES. Fundo Clima. 2018g. Disponível em: $<$ https://www.bndes.gov.br/wps/portal/site/home/financiamento/produto/fundoclima/fundo-clima>. Acesso em: 15 maio 2018.

BNDES. BANCO NACIONAL DE DESENVOLVIMENTO ECONÔMICO E SOCIAL - BNDES. Aplicação de US\$ 1 bilhão em energia eólica é tema de relatório inédito sobre green bonds do BNDES. 2018h. Disponível em: $<$ https://www.bndes.gov.br/wps/portal/site/home/imprensa/noticias/conteudo/aplic acao-de-us\$-1-bilhao-em-energia-eolica-e-tema-de-relatorio-inedito-sobre-greenbonds-do-

bndes/!ut/p/z1/zVPBbslwDP2WSevRSkoLLceOoaEB4zA2aC8oaUybqU1KG2Db 1y9Fu7JqQkzLJbJsv_cc55GErEmi2EFmzEitWGHjOBIsZsPpeOIv6Iz2Iz6N7r3Afw nGdBr2yCtJSJlqU5mcxFwJbDZSNUaafXpCcGiuS3SoLKsaVcMcqrSRqWSNQ1 OtDO6FdiirCpmylGkQCPvmFlzgsshtjCWgwjqTDFC3RYBgsGRtYYOFM7qWGqR CIY2GRvMalasRFXCtRANCw0IVK7NKpSBxOGBbHloBpMKj4DPuwpBbNNcVg R9y3g-

8gKy65k5smp45EbX9SVdJbCmC8xQeWR0kHsmLOnVpN_H8ywkmXQyL3oUM HfD968IHV4X3_QvhH0_r_-EDWWfJt90uiax9Wh-8G7L-

z_6xenv1fDTP7DMwk9uW $\mathrm{rSbrPyCuyjLOPkB93j3Bw4iHx-}$

W2_L5WYRPdfAFvPnWW/dz/d5/L2dBISEvZ0FBIS9nQSEh/>. Acesso em: 16 maio 2018.

BNDES. BANCO NACIONAL DE DESENVOLVIMENTO ECONÔMICO E SOCIAL - BNDES. Abastecimento de Água e Esgotamento Sanitário: Guias Socioambientais do BNDES. 2014a. Disponível em: <https://www.bndes.gov.br/wps/wcm/connect/site/f533cb52-2cf3-4993-948294e33b8b1f52/GuiaSocioAmbiental_Agua_e_Esgoto.pdf?MOD=AJPERES\&CVI

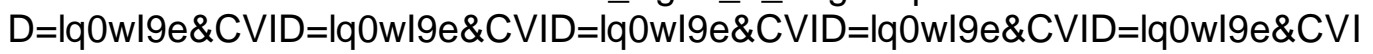
$\mathrm{D}=\mathrm{lq} 0 \mathrm{w} \mid \mathrm{e}$ e $>$. Acesso em: 21 maio 2018.

BNDES. BANCO NACIONAL DE DESENVOLVIMENTO ECONÔMICO E SOCIAL - BNDES. Setor Soja: Guias Socioambientais do BNDES. 2014b. Disponível em: <https://www.bndes.gov.br/wps/wcm/connect/site/7bf4e66b-5ffc$4 \mathrm{e} 8 \mathrm{e}-\mathrm{b} 3 \mathrm{~b} 3-$

1989cdd0fa29/GuiaSocioAmbiental_Soja.pdf?MOD=AJPERES\&CVID=lq0yFvt\& CVID=lq0yFvt\&CVID=lq0yFvt>. Acesso em: 21 maio 2018.

BNDES. BANCO NACIONAL DE DESENVOLVIMENTO ECONÔMICO E SOCIAL - BNDES. Política Socioambiental. 2016c. Disponível em: <https://www.bndes.gov.br/wps/portal/site/home/quem-somos/responsabilidadesocial-e-ambiental/o-que-nos-orienta/politicas/politica-socioambiental/politicasocioambiental/!ut/p/z1/zVRNk5pAEP01HHFGPgRyQ0PwA9c1lqtw2Rpg0NnAD A6jZvPr05Kt7EZXU6m9hAM1dL_ufv2aHpSgNUo4ObANUUxwUsJ3nPQel28SD K0ZjvCib2L_szOyo9DD4dJBqxaArzw-Rsnb-

FkUOtiPwtlosbjHbreHHICCkoyrWm1RnPKcNo-

MN4qpfdYy0PBWVFTDuz2t9EZUotGwpE0teENSVrKc5BTsGSOITqqUUa5OQU KHAJ2LRheytWm4FiVTLCPN67ENFG_CrjhOHOuM5SjOs8IzXUzObgEvqc6uuvmlt51CKaWid0eNV40uSFacluy1aneH7JZD-

Cw7TAam9jAC_scgl3AA8Bk4MzG3nyO8TkgvL_7AoB5H4eB1Z1MjlsSIzPA_nA Q2VYw6Yae-

QK4QTOGNp2rbcJsVwdGj2jJhaxAw8U_qji8awXngxVupx8aH0w_PpvRxW8Ay8 WedrvEhw0QXNHvCq3_2xUAsoacDqYb0ICorc54ldD6d8bX40XgNQfosylFiu3z1PThdySFIRS2dILMG- 
VqptPGtbw8XjstNJ0NuLQSSVY6rYL2ZJumKLvyQRgKjnhUPyksBQIAOqScPpEK mAhwCwhCVx3B3GSrK3xHp-

taGA65zRQXS0r13zWv30NimlgWvH48KN_pyfp87GYKjv-

CZ_40lo!/dz/d5/L2dBISEvZOFBIS9nQSEh/>. Acesso em: 11 maio 2018.

BNDES. BANCO NACIONAL DE DESENVOLVIMENTO ECONÔMICO E SOCIAL - BNDES. BNDES adere ao Pacto Empresarial pela Integridade e contra a Corrupção. 2016e. Disponível em: < https://www.bndes.gov.br/wps/portal/site/home/imprensa/noticias/conteudo/2016 0323_pacto>. Acesso em: 17 maio 2018.

BNDES. BANCO NACIONAL DE DESENVOLVIMENTO ECONÔMICO E SOCIAL - BNDES. Diretrizes socioambientais para a pecuária bovina. $2016 \mathrm{f}$. Disponível em: <https://www.bndes.gov.br/wps/portal/site/home/quemsomos/responsabilidade-social-e-ambiental/o-que-nos-orienta/politicas/politicasocioambiental/diretrizes-socioambientais-pecuariabovina/!ut/p/z1/1VTfd5owFP5b-

sBjTBAQ3Btaip3Ydu2syosnQIBskNAkatu_fpF166ZHdjx9Gk_h_vq-93cwBguYczwlhZYUc5wpf9X8WAdDafBxL5FEXoYWci_dKdKByicO7CRRuATnw-

gvHp_EfHho8whnHKVKNKuEpYRuSaMqmo2qQtAwOVvCYGetqQGkhec2kgQW TDmcQJrWiGM6LtKcUVwHVCCVP7JA50AmBcAi5am4EaXIFFUyzfj20i_yMto4lo QV-J NtFJWhlusGCYpDwLWV4T7tJaQZXJPFs0zMtYLvEBrZtZSDJxiYCĀ2dLM1TICZvMnXoGHeruNjjna4wta3ugDAyDwNuL5GrA8aDm7uBZY6v7M OA8O7mCvnOlxEKA9ucTvtHFa6tAPmTceTYwdQMh784dPSx0jq4J0maA7jYUrK Dc8ZFra_fw5kyT_6J4H4Qobv8pP_B8p87h6jviV5I-

u3pKfb11nCmyLOCy_9pbTT_vpiNZ4WWBasSUJZzuPwN8n48AIHLM0C0ikXFk5 _vl88Sy9NwguREENHbCG0ulWrkJwMZaLfb9VoBewXf9hKhLU3bq2hbk1SRc8Q kx3Lm-JW85VS4HU-t_Ryk1T6OaAfWE6OSHLV8TL7kUg_8kDNs6nntWS_g31w7-2-

5mVRr2eB5VTbaOS9WFXhX1z8AKq83vA!/dz/d5/L2dBISEvZ0FBIS9nQSEh/>. Acesso em: 18 maio 2018.

BNDES. BANCO NACIONAL DE DESENVOLVIMENTO ECONÔMICO E SOCIAL - BNDES. Cláusula social. 2016g. Disponível em: <https://www.bndes.gov.br/wps/portal/site/home/quem-somos/responsabilidadesocial-e-ambiental/o-que-fazemos/relacionamento-

clientes/!ut/p/z1/xZTNdpswEIWfpQuWsmSQAXdHbIJTaP5Tx2x8BAhQCxJGYNIfQVxsnATfNosyk6amTvfXBhgCB9hyMmeZaRhgpNCnTehuQ3mvrvCVyhAd2cGc pbWxSzw5sjHBlwPCeidx0EwHK_BkMYxrypmhxulp5QuWVcNqxp44FAQ7koqY a4AExFnzRUU1kJLknECpaQhAIpYkYKQMqlUd70JQLsWgpS8ouWQvYVBRnU ShUXIC76PKoCcUFa2RbkINGjVDFL4MZGFjL0OAImtgnAuhkBW8c6iFPbis3ESj FGh9FHZgvHnVn3_U4ojCV4wfQ44WqpwJ3lwry8No3p4hwfJ3jXI-

flmd2clc_FU9_X_1C 4 MFzkrBbBDLv-1Ju_MlzMsVE-

WO9OoV̆q94x28IGLulQm3_2lzauTHYwPdhiXX-

APyn859ZbVkrHvu13oqE0Q6st8auDj_14FBZ0VInr-

BTg8MuwMhjVNaU3rSVur67xpKvIZQxrqum4y8E4ysZ9EtbqplGQI6gFBsoa-

sCuYUrU4sLxNT_-FnyiDmHzWEK_1b8HnQip_j5IhVT6UtvET_Lh1b-

3uPs2zcvvVNWbF̄lzb0vn0G-BKUTA!/dz/d5/L2dBISEvZ0FBIS̄9nQSEh/>.

Acesso em: 19 maio 2018.

BNDES. BANCO NACIONAL DE DESENVOLVIMENTO ECONÔMICO E SOCIAL - BNDES. Sobre a Lei de Acesso à Informação e o SIC. 2016h. Disponível em: <https://www.bndes.gov.br/wps/portal/site/home/acesso-a- 
informacao/perguntas-frequentes/sobre-lei-acesso-informacao-sic\#1.3>. Acesso em: 19 maio 2018.

BNDES. BANCO NACIONAL DE DESENVOLVIMENTO ECONÔMICO E SOCIAL. PLANO PLURIANUAL DE IMPLEMENTAÇÃO DA PRSA 20152017: VERSÃO 12.05.2017. Brasil: Banco Nacional de Desenvolvimento Social e Econômica - BNDES, 2017i. Disponível em: $<$ https://www.bndes.gov.br/wps/wcm/connect/site/f36c61a9-f1c3-4a84-b6e36f6caa939c46/PRSA-

Plano.pdf?MOD=AJPERES\&CVID=IRr8oW8\&CVID=IRr8oW8\&CVID=IRnj4nr\&C VID=IRnj4nr>. Acesso em: 20 maio 2018.

BNDES. BANCO NACIONAL DE DESENVOLVIMENTO ECONÔMICO E SOCIAL. Sobre a lei de acesso à informação no 12.527/2011. Disponível em: $<$ https://www.bndes.gov.br/wps/portal/site/home/acesso-a-informacao/acessoinformacao-lei-acesso-informacao>. Acesso em: 06 maio 2018.

BNDES. BANCO NACIONAL DE DESENVOLVIMENTO ECONÔMICO E SOCIAL. BALANÇO DA IMPLEMENTAÇÃO DA PRSA VERSÃO 31.12.2017. Brasil: Banco Nacional de Desenvolvimento Social e Econômica - Bndes, 2017c. Disponível em: <https://www.bndes.gov.br/wps/wcm/connect/site/06130b2268a4-4a85-b5be-731cbe6dc931/Relatorio_PRSA_2015 2017.pdf?MOD=AJPERES\&CVID=me7RgNp>. Acesso em: 23 maio 2018.

BNDES. BANCO NACIONAL DE DESENVOLVIMENTO SOCIAL E ECONÔMICA - BNDES. RELATÓRIO ANUAL 2016. 2016d. Disponível em: $<$ https://www.bndes.gov.br/SiteBNDES/bndes/bndes_pt/Hotsites/Relatorio_Anual 2016/index.html>. Acesso em: 21 maio 2018.

BNDES. BANCO NACIONAL DE DESENVOLVIMENTO SOCIAL E ECONÔMICO. Pecuária Bovina de Corte: Guias Socioambientais do BNDES. Brasil: Banco Nacional de Desenvolvimento Social e Econômico, 2014. Disponível em: <https://www.bndes.gov.br/wps/wcm/connect/site/2078887c-1def45ef-892f-

b09c8c692a5d/GuiaSocioAmbiental_pecuaria_bovina.pdf?MOD=AJPERES\&CVI $\mathrm{D}=\mathrm{lq} 0 \mathrm{ByoD} \& \mathrm{CVID}=\mathrm{lq} 0 \mathrm{ByoD} \& \mathrm{CVID}=\mathrm{lq} 0 \mathrm{ByoD} \& \mathrm{CVID}=\mathrm{lq} 0 \mathrm{ByoD}>$. Acesso em: 19 maio 2018.

BRASIL. Circular no 3.678, de 31/10/2013. Dispõe sobre a divulgação de informações referentes à gestão de riscos, à apuração do montante dos ativos ponderados pelo risco (RWA) e à apuração do Patrimônio de Referência (PR). Disponível em: $<$ http://www.bcb.gov.br/pre/normativos/busca/normativo.asp?tipo=circ\&ano=2013 \&numero=3678\& $r=1>$. Acesso em: 17 de maio de 2018.

BRASIL. EMBRAPA. Entenda a Lei 12.651 de 25 de maio de 2012. 2012a. Disponível em:<https://www.embrapa.br/codigo-florestal/entenda-o-codigoflorestal>. Acesso em: 05 maio 2018.

BRASIL. Instituto Nacional de Metrologia Qualidade e Tecnologia. Ministério do Desenvolvimento Indústria e Comércio Exterior. Conheça alguns pontos da norma. Disponível em: <http://www.inmetro.gov.br/qualidade/responsabilidade_social/pontos-iso.asp>. Acesso em: 30 abr. 2018. 
BRASIL. Lei Federal ํo 10.743, DE 9 DE OUTUBRO DE 2003. Institui no Brasil o Sistema de Certificação do Processo de Kimberley SCPK, relativo à exportação e à importação de diamantes brutos, e dá outras providências. Brasília, DF, out 2003.

BRASIL. Lei Federal № 7.724, DE 16 DE MAIO DE 2012. Regulamenta a Lei no 12.527, de 18 de novembro de 2011, que dispõe sobre o acesso a informações previsto no inciso XXXIII do caput do art. 5o, no inciso II do § 30 do art. 37 e no § 20 do art. 216 da Constituição. Brasília, DF, maio 2012.

BRASIL. Lei Federal № 9.605, de 12 de fevereiro de 1998. Dispõe sobre as sanções penais e administrativas derivadas de condutas e atividades lesivas ao meio ambiente, e dá outras providências. Brasília, DF, fev 1998.

BRASIL. Lei no 6.938, de 31 de agosto de 1981. Dispõe sobre a política nacional do meio ambiente, seus fins e mecanismos de formulação e aplicação, e da outras providências. Brasília, DF, ago 1981.

BRASIL. Ministério do Meio Ambiente - MMA. Política Nacional de Resíduos Sólidos. 2010. Disponível em: <http://www.mma.gov.br/política-de-resíduossólidos>. Acesso em: 04 maio 2018.

BRASIL. MINISTÉRIO DO MEIO AMBIENTE - MMA. Política Nacional sobre Mudança do Clima. 2009. Disponível em: <http://www.mma.gov.br/clima/politica-nacional-sobre-mudanca-do-clima>.

Acesso em: 04 maio 2018.

BRASIL. MINISTÉRIO DO PLANEJAMENTO DESENVOLVIMENTO E GESTÃO. Regulamentação da Lei das Estatais - Decreto no 8.945, de 27.12.2016. 2016a. Disponível em: <http://www.planejamento.gov.br/apresentacoes/2016/161228_coletiva-

regulamentacao-da-lei-das-estatais.pdf/view>. Acesso em: 06 maio 2018. regulamentacao-da-lei-das-estatais.pdf/view>. Acesso em: 06 maio 2018.

BRASIL. PORTAL BRASIL. Entenda o que muda com a nova Lei das Estatais: Gestão. 2016. Disponível em: <http://www.brasil.gov.br/governo/2016/06/entenda-o-que-muda-com-a-nova-leidas-estatais>. Acesso em: 06 maio 2018.

BTG PACTUAL DIGITAL (Brasil). 0 que é Instituição Financeira e quais o Banco Central supervisiona? 2018. Disponível em: <O que é Instituição Financeira e quais o Banco Central supervisiona? >. Acesso em: 06 maio 2018.

CALDAS, Roberto Correia da Silva Gomes; MARTINS, Thiago Penido. Princípios do Equador e Governança Re- gulatória nas contratações públicas sustentá- veis: implicações nas desapropriações. 2016. Revista Brasileira de Estudos Políticos | Belo Horizonte. Disponível

em:

<https://pos.direito.ufmg.br/rbep/index.php/rbep/article/view/P.0034-

7191.2016V112P183/344>. Acesso em: 28 abr. 2018.

$\begin{array}{lccr}\text { CEBDS - CONSELHO } & \text { EMPRESARIAL } & \text { BRASILEIRO PARA } & \text { O } \\ \text { DESENVOLVIMENTO } & \text { SUSTENTÁVEL } & \text { (Brasil). Câmaras } \\ \text { Temáticas: Finanças. } & 2005 . & \text { Disponível } & \text { em: } \\ \text { <http://cebds.org/camaras_tematicas/financas/>. Acesso em: } 01 \text { nov. 2018. } & \end{array}$


COMPÊNDIO PARA A SUSTENTABILIDADE. IFC - Princípios do Equador. Disponível em: <http://www.institutoatkwhh.org.br/compendio/?q=node/41>. Acesso em: 27 abr. 2018.

CORPORAÇÃO FINANCEIRA INTERNACIONAL - INICIATIVA FINANCEIRA. Grupo Banco Mundial. SOBRE A IFC. 2017a. Disponível em: $<\mathrm{https}$ ://www.ifc.org/wps/wcm/connect/multilingual_ext_content/ifc_external_corp orate_site/home_pt>. Acesso em: 30 abr. 2018.

CORPORAÇÃO FINANCEIRA INTERNACIONAL - INICIATIVA FINANCEIRA. Grupo Banco Mundial. Padrões de Desempenho sobre Sustentabilidade Socioambiental. 2012d. Disponível em: <https://www.ifc.org/wps/wcm/connect/dfa5bc804d0829b899f3ddf81ee631cc/PS

_Portuguese_2012_Full-Document.pdf?MOD=AJPERES>. Acesso em: 24 maio 2018.

CORPORAÇÃO FINANCEIRA INTERNACIONAL - INICIATIVA FINANCEIRA. Recursos para empresas.2018b. Disponível em: $<$ https://www.ifc.org/wps/wcm/connect/Topics_Ext_Content/IFC_External_Corpor ate_Site/Sustainability-At-IFC/Company-Resources >. Acesso em: 01 maio 2018.

CORPORAÇÃO FINANCEIRA INTERNACIONAL - INICIATIVA FINANCEIRA. Sustentabilidade. 2018c. Disponível em: $<$ https://www.ifc.org/wps/wcm/connect/Topics_Ext_Content/IFC_External_Corpor ate_Site/Sustainability-At-IFC>. Acesso em: 01 maio 2018.

CRESWEU, John W.. PROJETO DE PESQUISA: Métodos qualitativo, quantitativo e misto. 2. ed. Porto Alegre: Artmed, 2007. Tradução: Luciana de Oliveira da Rocha. Disponível em: $<$ https://edisciplinas.usp.br/pluginfile.php/696271/mod_resource/content/1/Cresw ell.pdf>. Acesso em: 08 maio 2018.

DIAS, Reinaldo. Gestão Ambiental: Responsabilidade social e sustentabilidade.1.ed. 2. reimpr. São Paulo: Atlas, 2007.

DIAS, Reinaldo. Gestão Ambiental: Responsabilidade Social e Sustentabilidade. 2. ed. São Paulo: Atlas, 2011.

EDUARDO SIMÕES REUTERS. Bancos adotam Protocolo Verde, mas vantagem no crédito é incerta. 2009. Disponível em: <http://www.estadao.com.br/noticias/geral,bancos-adotam-protocolo-verde-masvantagem-no-credito-e-incerta,397408>. Acesso em: 01 abr. 2018.

FEBRABAN - FEDERAÇÃO BRASILEIRA DE BANCOS (Brasil). Guia para Emissão de Títulos Verdes no Brasil. 2016. Disponível em: <https://portal.febraban.org.br/pagina/3188/52/pt-br/guia-titulos-verdes>. Acesso em: 26 abr. 2018.

ÍNDICE DE SUSTENTABILIDADE EMPRESARIAL. O que é o ISE. 2017. Disponível em: <http://isebvmf.com.br/o-que-e-o-ise?locale=pt-br>. Acesso em: 01 abr. 2018. 
INSTITUTO ETHOS DE EMPRESAS E RESPONSABILIDADE SOCIAL E FEDERAÇÃO BRASILEIRA DE BANCOS (FEBRABAN). Indicadores Setoriais Ethos-Febraban de Responsabilidade Social Empresarial. 2008. Disponível em:<https://www3.ethos.org.br/wp-

content/uploads/2012/07/INDICADORESETHOS-FEBRABAN2008-FINAL.pdf>. Acesso em: 23 abr. 2018.

INSTITUTO ETHOS. Indicadores Ethos para Negócios Sustentáveis e Responsáveis. 2012a. Disponível em: < https://www3.ethos.org.br/conteudo/indicadores/\#.WxH0-e4vzIU>. Acesso em: 30 de março de 2018.

INSTITUTO ETHOS. Sobre o Instituto. 2012. Disponível em: $<\mathrm{https}$ ://www3.ethos.org.br/conteudo/sobre-o-instituto/\#.WxHyl-4vzlU>. Acesso em: 30 de março de 2018.

INSTITUTO NACIONAL DE METROLOGIA QUALIDADE E TECNOLOGIA (Brasil). Ministério do Desenvolvimento Indústria e Comércio Exterior. ISO 26000. $2010 . \quad$ Disponível em: <http://www.inmetro.gov.br/qualidade/responsabilidade_social/iso26000.asp>. Acesso em: 30 abr. 2018.

INSTITUTO NACIONAL DE METROLOGIA QUALIDADE E TECNOLOGIA (Brasil). A Norma Nacional - ABNT NBR 16001.2004. Disponível em: <http://www.inmetro.gov.br/qualidade/responsabilidade_social/norma_nacional.a sp>. Acesso em: 30 abr. 2018.

MAXIMIANO, Antonio Cesar Amaru. Introdução à Administração. 7. ed. São Paulo: Atlas, 2009.

NAÇÕES UNIDAS NO BRASIL (Brasil). Programa das Nações Unidas para o Desenvolvimento (PNUD). 2017. Disponível em: <https://nacoesunidas.org/onue-bndes-reafirmam-importancia-das-parcerias-para-a-conquista-dos-objetivosglobais/>. Acesso em: 17 maio 2018.

NASCIMENTO, Luis Felipe. Gestão ambiental e sustentabilidade. Florianópolis: Departamento de Ciências da Administração / UFSC; [Brasília]: CAPES: UAB, 2012.

ORGANIZAÇÃO DAS NAÇÕES UNIDAS (Brasil) (Org.). Transformando Nosso Mundo: A Agenda 2030 para o Desenvolvimento Sustentável. Disponível em: <https://nacoesunidas.org/pos2015/agenda2030/>. Acesso em: 30 mar. 2018.

PACTO GLOBAL. O que é? Disponível em: <http://pactoglobal.org.br/o-que-e/>. Acesso em: 30 mar. 2018.

PENSAMENTO VERDE (Brasil). A importância do Protocolo Verde para o desenvolvimento de soluções sustentáveis no Brasil. 2013. Disponível em: $<$ http://www.pensamentoverde.com.br/sustentabilidade/importancia-protocoloverde-desenvolvimento-solucoes-sustentaveis-brasil/>. Acesso em: 01 maio 2018. 
PRODANOV, Cleber Cristiano; FREITAS, Ernani Cesar de. Metodologia do trabalho científico: Métodos e Técnicas da Pesquisa e do Trabalho Acadêmico. 2. ed. Novo Hamburgo: Feevale, 2013. Disponível em: <http://www.feevale.br/Comum/midias/8807f05a-14d0-4d5b-b1ad-

1538f3aef538/E-book Metodologia do Trabalho Cientifico.pdf>. Acesso em: 07 maio 2018.

PROGRAMA DAS NAÇÕES UNIDAS PARA O MEIO AMBIENTE - INICIATIVA FINANCEIRA (Suíça). SOBRE O PROGRAMA DE AMBIENTE DAS NAÇÕES UNIDAS - INICIATIVA FINANCEIRA. 2017. Disponível em: <http://www.unepfi.org/about/>. Acesso em: 28 abr. 2018.

PROGRAMA DAS NAÇÕES UNIDAS PARA O MEIO AMBIENTE - INICIATIVA FINANCEIRA (Suíça). Setor bancário 2017b. Disponível em: <http://www.unepfi.org/banking/banking/>. Acesso em: 28 abr. 2018.

PROGRAMA DAS NAÇÕES UNIDAS PARA O MEIO AMBIENTE - INICIATIVA FINANCEIRA (Suíça). AMÉRICA LATINA E MEMBROS DO CARIBE. 2017a. Disponível em: <http://www.unepfi.org/members/latin-america-caribbean/>. Acesso em: 28 abr. 2018.

REDE BRASIL DO PACTO GLOBAL (Brasil). Afinal, o que são os 10 princípios do \#PactoGlobal? 2018. Disponível em: <https://www.facebook.com/pactoglobalbr/photos/a.712358218799814.10737418 28.578571138845190/1613141255388168/?type=3\&theater $>$. Acesso em: 18 abr. 2018.

SIMÕES, Claudia Pestana et al. Responsabilidade Social e Cidadania: Conceitos e Ferramentas. Brasília: Sesi - Departamento Nacional, 2008.

SOCIAL ACCOUNTABILITY INTERNATIONAL (SAI) (Nova York). Norma SA8000. Disponível em: <http://www.saintl.org/_data/global/files/SA8000Standard_Portugues(1).pdf>. Acesso em: 29 abr. 2018.

TACHIZAWA, Takeshy; MENDES, Gildásio. Como Fazer Monografia na Prática. 2. ed. Rio de Janeiro: Fundação Getúlio Vargas, 1999.

VERGARA, Sylvia Constant. Métodos de Pesquisa em Administração. 5. ed. São Paulo: Atlas, 2012.

YOSHIDA, Consuelo Y. Moromizato et al (Org.). Finanças Sustentáveis e a Responsabilidade Socioambiental das Instituições Financeiras. Belo Horizonte: Fórum, 2017. 